\title{
Mouse homologues of human hereditary disease
}

\author{
A G Searle, J H Edwards, J G Hall
}

\begin{abstract}
Details are given of 214 loci known to be associated with human hereditary disease, which have been mapped on both human and mouse chromosomes. Forty two of these have pathological variants in both species; in general the mouse variants are similar in their effects to the corresponding human ones, but exceptions include the Dmd/DMD and Hprt/ HPRT mutations which cause little, if any, harm in mice. Possible reasons for phenotypic differences are discussed. In most pathological variants the gene product seems to be absent or greatly reduced in both species. The extensive data on conserved segments between human and mouse chromosomes are used to predict locations in the mouse of over 50 loci of medical interest which are mapped so far only on human chromosomes. In about $80 \%$ of these a fairly confident prediction can be made. Some
\end{abstract} likely homologies between mapped mouse loci and unmapped human ones are also given. Sixty six human and mouse proto-oncogene and growth factor gene homologies are also listed; those of confirmed location are all in known conserved segments. A survey of 18 mapped human disease loci and chromosome regions in which the manifestation or severity of pathological effects is thought to be the result of genomic imprinting shows that most of the homologous regions in the mouse are also associated with imprinting, especially those with homologues on human chromosomes 11p and 15q. Useful methods of accelerating the production of mouse models of human hereditary disease include (1) use of a supermutagen, such as ethylnitrosourea (ENU), (2) targeted mutagenesis involving ES cells, and (3) use of gene transfer techniques, with production of 'knockout mutations'.

\section{( $\mathcal{F}$ Med Genet 1994;31:1-19)}

The need to develop good animal models of human hereditary disease has been recognised ever since the subject was first reviewed ${ }^{12}$ but, until recently, progress in this field has been slow. It is clear that the most relevant models are likely to emerge when the comparable. human and animal conditions are known to involve homologous loci. In this respect our genetic knowledge of the laboratory mouse outstrips that for all other non-human mammals. The 829 loci recently assigned to both human and mouse chromosomes ${ }^{3}$ has now risen to 900 , well above comparable figures for other laboratory or farm animals. In a previous publication, ${ }^{4} 102$ loci were listed which were associated with specific human disease, had mouse homologues, and had been located in both species. The number has now more than doubled (table 1A). Of particular interest are those which have pathological variants in both the mouse and humans: these are listed in table 2. Many other pathological mutations have been detected and located in the mouse; about half these appear to lie in conserved chromosomal segments. Thus the likely position of their human homologues can be predicted with some confidence.

\section{Homologous loci}

Table 1A lists 187 autosomal and 27 sex linked loci associated with pathological effects, which have been located on both human and mouse chromosomes. ${ }^{3}$ They are ordered in terms of the associated human disease(s), sometimes with two entries for particular loci. For ease of reference, table $1 \mathrm{~B}$ has a tabulation of the same set in alphabetical order of human gene symbols. ${ }^{5}$ The MIM number, location, etc come from McKusick's catalogue ${ }^{6}$ and other work, ${ }^{7}$ which also gives details of the disorders. Schinzel et $a l^{8}$ also list human clinical disorders with chromosomal localisations of the genes concerned. Information on corresponding mouse genes is given in several publications, ${ }^{3910}$ while the latest locus map of the mouse $^{11}$ has been used to show mouse gene locations as distances in centimorgans from the centromere (figures after the full stop). When there is a double zero after the full stop the gene concerned has not yet been localised on the linkage map. Positions of mouse loci on the $\mathrm{G}$ banded map are derived from the Mouse Chromosome Atlas. ${ }^{12}$ References given in table 1 are for recently reported disease homologies; for earlier ones please consult Human Gene Mapping $11 .^{13}$

With reference to polycystic kidney disease ${ }^{51}$ it should be noted that the mouse $P k d-1$ locus has not been identified but two flanking DNA markers to the human PKD1 locus were used to show that the region concerned mapped to mouse chromosome 17. Some unconfirmed

Correspondence to Dr Searle 
Table $1 A$ Mapping and other data on loci for human hereditary diseases which have been assigned to human and mouse chromosomes. In Disease name, a dash signifies deficiency and + an excess. A variant which may not be harmful is indicated by (v) after the name. Some loci associated with more than one disease are entered twice. For further information see text

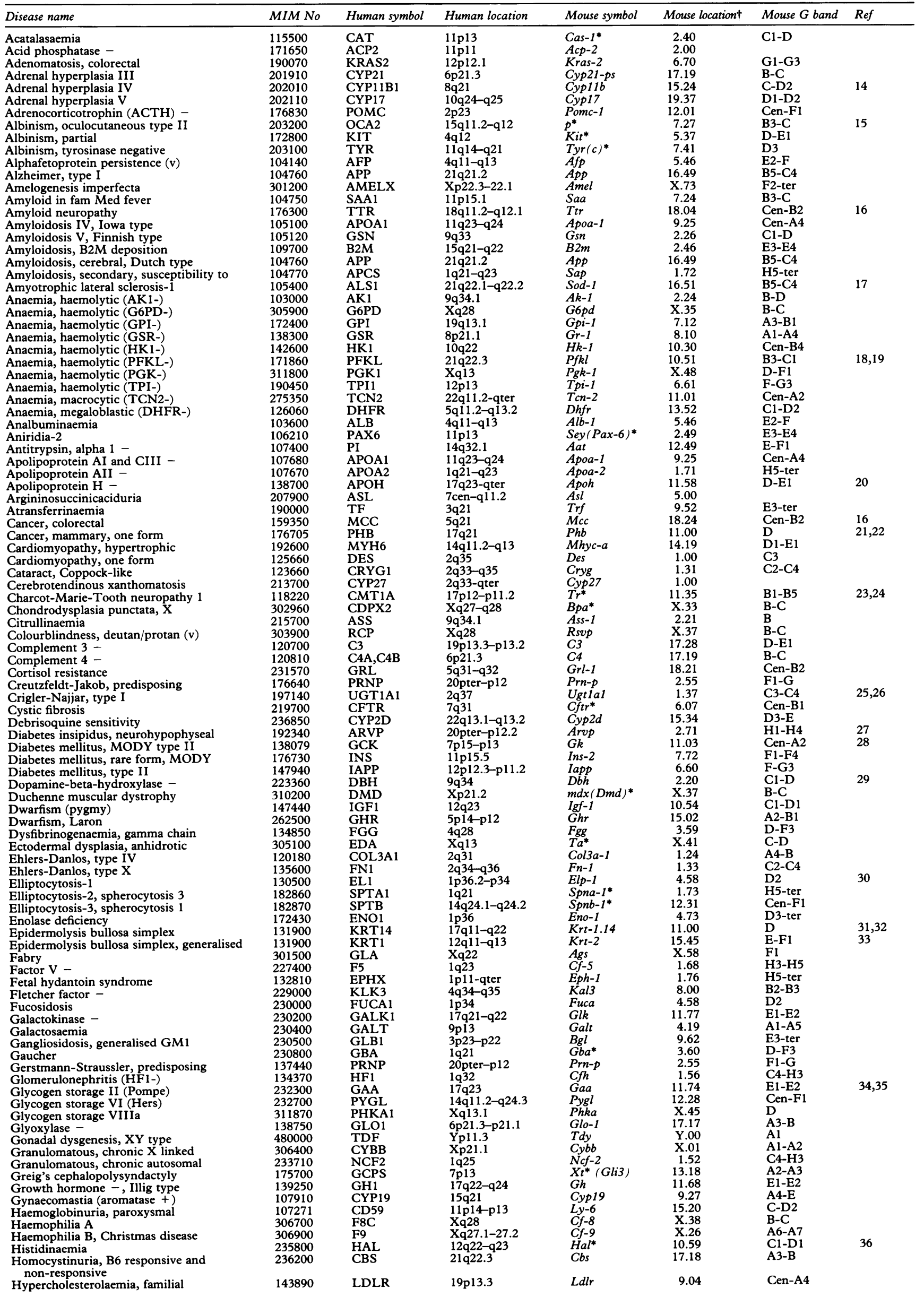


Table 1A-contd

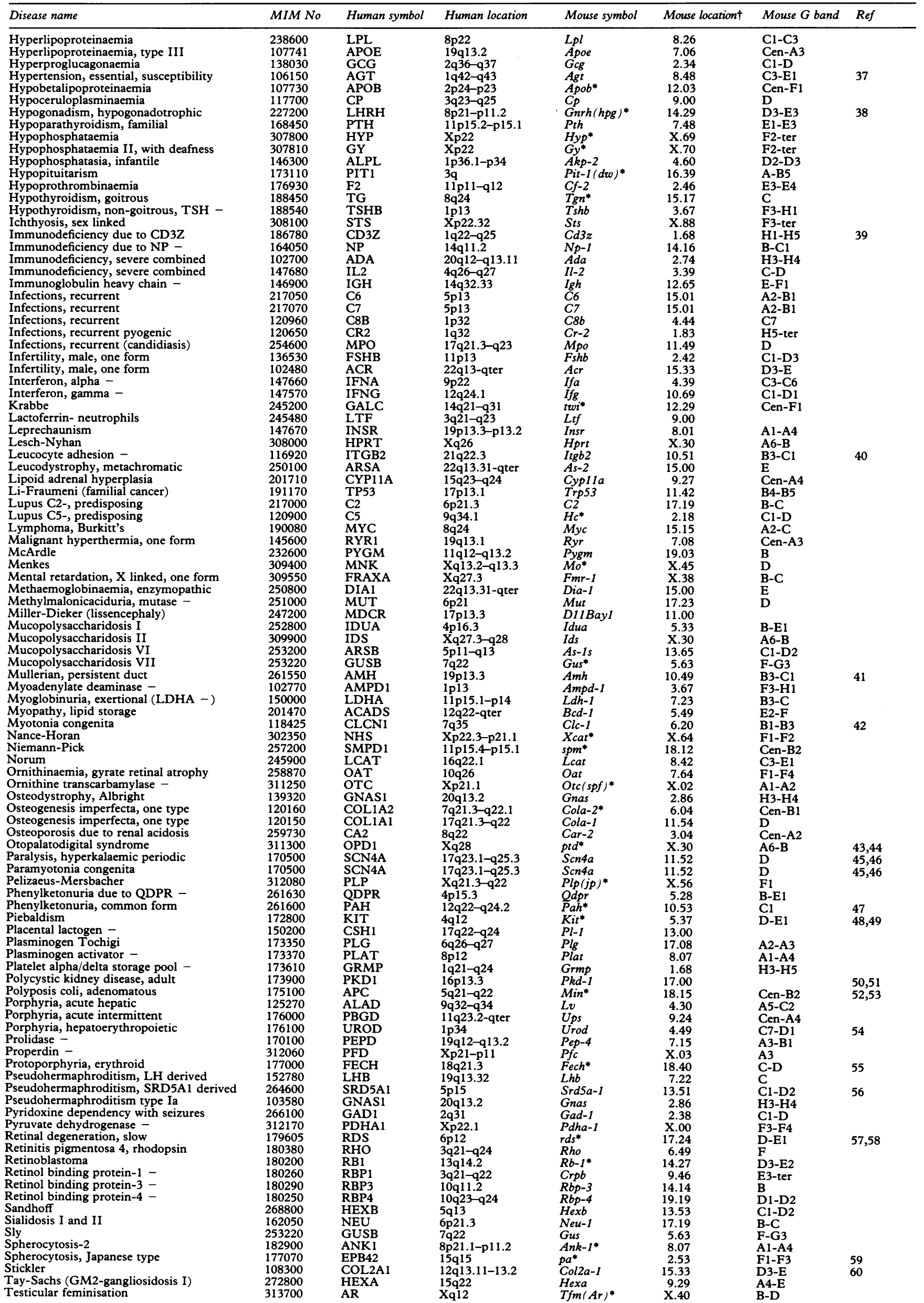


Table 1A-contd

\begin{tabular}{|c|c|c|c|c|c|c|c|}
\hline Disease name & $M I M N o$ & Human symbol & Human location & Mouse symbol & Mouse location $\dagger$ & Mouse $G$ band & Ref \\
\hline Thalassaemia, alpha & 141800 & HBA1 & $16 \mathrm{p} 13.3$ & $H b a^{*}$ & 11.14 & A1-B1 & \\
\hline Thalassaemia, beta & 141900 & HBB & $11 \mathrm{p} 15.5$ & $H b b^{*}$ & 7.49 & & \\
\hline Thrombophilia & 107300 & AT3 & $1 \mathrm{q} 23-\mathrm{q} 25$ & $A t-3$ & 1.66 & H3-H5 & \\
\hline Thyroid hormone defect & 274500 & TPO & $2 \mathrm{p} 13$ & $T p o$ & 12.09 & Cen-F1 & \\
\hline Thyroid hormone unresponsiveness & 190120 & THRA1 & $17 \mathrm{q} 11.2-\mathrm{q} 12$ & Erba & 11.56 & D-E1 & \\
\hline Thyrotropin unresponsiveness & 275200 & TSHR & $14 q 24-q 31$ & Tshr & 12.48 & E-Fi & \\
\hline Trypsinogen - & 276000 & TRY1 & $7 \mathrm{q} 32$-qter & Try-1 & 6.20 & B1-B3 & \\
\hline Tyrosinaemia I & 276700 & FAH & $15 \mathrm{q} 23-\mathrm{q} 25$ & Fah & 7.41 & & 61 \\
\hline Tyrosinaemia II & 276600 & TAT & $16 \mathrm{q} 22.1$ & Tat & 8.46 & C3-E1 & \\
\hline Urolithiasis, 2,8-dihydroxyadenine & 102600 & APRT & $16 \mathrm{q} 24$ & Aprt & 8.63 & E1-ter & \\
\hline Waardenburg, PAX 3 related & 193500 & PAX3 & $2 \mathrm{q} 35$ & $S p(\operatorname{Pax}-3)^{*}$ & 1.36 & $\mathrm{C} 3$ & 62 \\
\hline Wilms's tumour & 194070 & WT1 & $11 \mathrm{p} 13$ & $W t-1$ & 2.41 & C1-D & \\
\hline Wolf-Hirschhorn & 142983 & HOX7 & $4 \mathrm{p} 16.1$ & Hox-7 & 5.14 & B-E1 & \\
\hline Wolman & 278000 & LIPA & $10 \mathrm{q} 24-\mathrm{q} 25$ & $L_{i p-1}$ & 19.00 & & \\
\hline Xeroderma pigmentosum IX & 278700 & $\mathrm{XPA}$ & $9 \mathrm{q} 32-\mathrm{q} 34.1$ & $X p a$ & 4.00 & C2 & \\
\hline Xeroderma pigmentosum, group D & 126340 & ERCC2 & $19 \mathrm{q} 13.2-\mathrm{q} 13.3$ & Ercc-2 & 7.06 & Cen-A3 & 63 \\
\hline
\end{tabular}

* Mouse gene with pathological allele.

† Given as chromosome number, followed after full stop by estimated distance of locus from centromere in cM. A double zero indicates that regional location is unknown.

Table $1 B$ Data from table $1 A$ shown in alphabetical order of human locus symbols with associated diseases

\begin{tabular}{|c|c|c|c|c|c|}
\hline Symbol & Name of disease & Symbol & Name of disease & Symbol & Name of disease \\
\hline $\begin{array}{l}\text { ACADS } \\
A C P 2\end{array}$ & Myopathy, lipid storage & EPB42 & Spherocytosis, Japanese type & LTF & Lactoferrin- neutrophils \\
\hline $\begin{array}{l}\mathrm{ACP2} \\
\mathrm{ACR}\end{array}$ & Acid phosphatase - & EPHX & Fetal hydantoin syndrome & & \\
\hline $\begin{array}{l}\text { ACR } \\
\text { ADA }\end{array}$ & Infertility, male, one form & ERCC2 & Xeroderma pigmentosum, group D & MDCR & Miller-Dieker (lissencephaly) \\
\hline $\begin{array}{l}\text { ADA } \\
\text { AFP }\end{array}$ & Immunodeficiency, severe combined & & Hypoprothrombinaemia & MNK & Menkes \\
\hline $\begin{array}{l}\text { AFP } \\
\text { AGT }\end{array}$ & Alphafetoprotein persistence (v) & F5 & Factor $\mathrm{V}-$ & MPO & Infections, recurrent (candidiasis) \\
\hline $\begin{array}{l}\text { AGT } \\
\text { AKI }\end{array}$ & Hypertension, essential, susceptibility & F8C & Haemophilia A & MUT & Methylmalonicaciduria, mutase - \\
\hline $\begin{array}{l}\text { AK1 } \\
\text { ALAD }\end{array}$ & Anaemia, haemolytic (AK1-) & $\begin{array}{l}\text { F9 } \\
\text { FAH }\end{array}$ & Haemophilia B, Christmas disease & & Lymphoma, Burkitt's \\
\hline $\begin{array}{l}\text { ALAD } \\
\text { ALB }\end{array}$ & $\begin{array}{l}\text { Porphyria, acute hepatic } \\
\text { Analbuminaemia }\end{array}$ & $\begin{array}{l}\text { FAH } \\
\text { FECH }\end{array}$ & & $\begin{array}{l}\text { MYH6 } \\
\text { NCF2 }\end{array}$ & $\begin{array}{l}\text { Cardiomyopathy, hypertrophic } \\
\text { Granulomatous, chronic autosomal }\end{array}$ \\
\hline ALPL & Hypophosphatasia, infantile & FGG & $\begin{array}{l}\text { Protoporphyria, erythroid } \\
\text { Dysfibrinogenaemia, gamma chain }\end{array}$ & NEU & $\begin{array}{l}\text { Granulomatous, chronic autosomal } \\
\text { Sialidosis I and II }\end{array}$ \\
\hline ALS1 & Amyotrophic lateral sclerosis-1 & FN1 & Ehlers-Danlos, type X & NHS & Nance-Horan \\
\hline AMELX & Amelogenesis imperfecta & FRAXA & Mental retardation, $\mathrm{X}$ linked, one & NP & Immunodeficiency due to NP - \\
\hline AMH & Mullerian, persistent duct & & form & OAT & Ornithinaemia, gyrate retinal atrophy \\
\hline AMPD1 & Myoadenylate deaminase - & FSHB & Infertility, male, one form & OCA2 & Albinism, oculocutaneous type II \\
\hline ANK1 & Spherocytosis-2 & FUCA1 & Fucosidosis & OPD1 & Otopalatodigital syndrome \\
\hline $\mathrm{APC}$ & Polyposis coli, adenomatous & G6PD & Anaemia, haemolytic (G6PD-) & OTC & Ornithine transcarbamylase - \\
\hline APCS & Amyloidosis, secondary, susceptibility to & GAA & Glycogen storage II (Pompe) & & Phenylketonuria, common form \\
\hline $\begin{array}{l}\text { APOA1 } \\
\text { APOA1 }\end{array}$ & $\begin{array}{l}\text { Apolipoprotein AI and CIII - } \\
\text { Amyloidosis IV, Iowa type }\end{array}$ & $\begin{array}{l}\text { GAD1 } \\
\text { GALC }\end{array}$ & $\begin{array}{l}\text { Pyridoxine dependency with seizures } \\
\text { Krabbe }\end{array}$ & PAX3 & Waardenburg, PAX3 related \\
\hline $\begin{array}{l}\text { APOA1 } \\
\text { APOA2 }\end{array}$ & Apolipoprotein AII - & GALK1 & $\begin{array}{l}\text { Krabbe } \\
\text { Galactokinase - }\end{array}$ & $\begin{array}{l}\text { PAX6 } \\
\text { PBGD }\end{array}$ & $\begin{array}{l}\text { Aniridia-2 } \\
\text { Porphyria, acute intermittent }\end{array}$ \\
\hline APOB & Hypobetalipoproteinaemia & GALT & $\begin{array}{l}\text { Galactokinase - } \\
\text { Galactosaemia }\end{array}$ & PDHAl & $\begin{array}{l}\text { Porphyria, acute intermittent } \\
\text { Pyruvate dehydrogenase - }\end{array}$ \\
\hline APOE & Hyperlipoproteinaemia, type III & GBA & Gaucher & PEPD & Prolidase - \\
\hline $\mathrm{APOH}$ & Apolipoprotein $\mathrm{H}-$ & GCG & roglucagonaemia & PFD & Properdin - \\
\hline APP & Amyloidosis, cerebral, Dutch type & GCK & Diabetes mellitus, MODY type II & PFKL & Anaemia, haemolytic (PFKL-) \\
\hline APP & Alzheimer, type I & GCPS & Greig's cephalopolysyndactyly & PGK1 & Anaemia, haemolytic (PGK-) \\
\hline APRT & Urolithiasis, 2,8-dihydroxyadenine & GH1 & Growth hormone -, Illig type & PHB & Cancer, mammary, one form \\
\hline & Testicular feminisation & GHR & Dwarfism, Laron & PHKAI & Glycogen storage VIIIa \\
\hline ARSA & Leucodystrophy, metachromatic & GLA & Fabry & PI & Antitrypsin, alpha 1 - \\
\hline ARSB & Mucopolysaccharidosis VI & GLB1 & Gangliosidosis, generalised GM1 & PIT1 & Hypopituitarism \\
\hline ARVP & Diabetes insipidus, neurohypophyseal & GLO1 & Glyoxylase - & PKDI & Polycystic kidney disease, adult \\
\hline ASL & Argininosuccinicaciduria & GNAS1 & trophy, A & PLAT & Plasminogen activator - \\
\hline ASS & Citrullinaemia & GNAS1 & Pseudohypoparathyroidism type Ia & PLG & Plasminogen Tochigi \\
\hline AT3 & Thro & GPI & Anaemia, haemolytic (GPI-) & PLP & Pelizaeus-Mersbacher \\
\hline B2M & Amyloidosis, B2M deposition & GRL & Cortisol resistance & POMC & Adrenocorticotrophin (ACTH) - \\
\hline & Lupus $\mathrm{C} 2-$, predisposing & GRMP & Platelet alpha/delta storage pool - & PRNP & Creutzfeldt-Jakob, predisposing \\
\hline & Complement 3 - & GSN & Amyloidosis V, Finnish type & PRNP & Gerstmann-Straussler, predisposing \\
\hline C4A,C4B & Complement 4 - & GSR & Anaemia, haemolytic (GSR-) & PTH & Hypoparathyroidism, familial \\
\hline & Lupus C5-, predisposing & GUSB & Mucopolysaccharidosis VII & PYGL & Glycogen storage VI (Hers) \\
\hline & Infections, recurrent & GUSB & Sly & PYGM & McArdle \\
\hline & Infections, recurrent & G & Hypophosphataemia II, with deafness & QDPR & Phenylketonuria due to QDPR - \\
\hline C8B & Infections, recurrent & HAL & Histidinaemia & $\mathbf{R B} 1$ & Retinoblastoma \\
\hline CA2 & Osteoporosis due to renal acidosis & HBAl & Thalassaemia, alpha & RBP1 & Retinol binding protein-1 - \\
\hline CAT & Acatalasaemia & HBB & Thalassaemia, beta & RBP3 & Retinol binding protein-3 - \\
\hline CBS & inuria, $\mathrm{B} 6$ responsive and & HEXA & Tay-Sachs (GM2-gangliosidosis I) & RBP4 & Retinol binding protein $-4-$ \\
\hline & & HEXB & $\mathrm{Sa}$ & $\begin{array}{l}\text { RCP } \\
\text { RDS }\end{array}$ & Colourblindness, deutan/protan (v) \\
\hline $\begin{array}{l}\text { CD3Z } \\
\text { CD59 }\end{array}$ & Immunodeficiency due to $\mathrm{CD} 3 \mathrm{Z}$ & $\mathrm{HF} 1$ & Glomerulonephritis (HF1-) & RDS & Retinal degeneration, slow \\
\hline CD59 & $\begin{array}{l}\text { uria, paroxysmal } \\
\text { lasia punctata, } X\end{array}$ & $\mathrm{HK}_{\mathrm{HOX}}$ & Anaemia, haemolytic (HK1-) & $\begin{array}{l}\text { RHO } \\
\text { RYR1 }\end{array}$ & $\begin{array}{l}\text { Retinitis pigmentosa 4, rhodopsin } \\
\text { Malignant hyperthermia, one form }\end{array}$ \\
\hline CDPX2 & $\begin{array}{l}\text { Chondrodysplasia punctata, } \mathrm{X} \\
\text { Cystic fibrosis }\end{array}$ & $\begin{array}{l}\text { HOX7 } \\
\text { HPRT }\end{array}$ & Wolf-Hirschhorn & $\begin{array}{l}\text { RYRI } \\
\text { SAA1 }\end{array}$ & $\begin{array}{l}\text { Malignant hyperthermia, one form } \\
\text { Amyloid in fam Med fever }\end{array}$ \\
\hline CFTR & $\begin{array}{l}\text { Cystic fibrosis } \\
\text { Myotonia cong }\end{array}$ & $\begin{array}{l}\text { HPRT } \\
\text { HYP }\end{array}$ & $\begin{array}{l}\text { Lesc } \\
\text { Hyp }\end{array}$ & SCN4A & $\begin{array}{l}\text { Amyloid in fam Med fever } \\
\text { Paralysis, hyperkalaemic periodic }\end{array}$ \\
\hline CLCN1 & $\begin{array}{l}\text { Myotonia congenit } \\
\text { Charcot-Marie-To }\end{array}$ & $\begin{array}{l}\text { HYP } \\
\text { IAPP }\end{array}$ & $\begin{array}{l}\text { hataemia } \\
\text { ellitus, type II }\end{array}$ & SCN4A & $\begin{array}{l}\text { Paralysis, hyperkalaemic perıodic } \\
\text { Paramyotonia congenita }\end{array}$ \\
\hline $\begin{array}{l}\text { CMT1A } \\
\text { COL1A1 }\end{array}$ & $\begin{array}{l}\text { Charcot-Marie-Tooth neuropathy } 1 \\
\text { Osteogenesis imperfecta, one type }\end{array}$ & IDS & $\begin{array}{l}\text { s mellitus, type II } \\
\text { lysaccharidosis II }\end{array}$ & SMPD1 & $\begin{array}{l}\text { Paramyotonia co } \\
\text { Niemann-Pick }\end{array}$ \\
\hline COL1A1 & $\begin{array}{l}\text { Osteogenesis imperfecta, one type } \\
\text { Osteogenesis imperfecta, one type }\end{array}$ & & $\begin{array}{l}\text { Mucopolysaccharidosis II } \\
\text { Mucopolysaccharidosis I }\end{array}$ & & \\
\hline COLLA2 & $\begin{array}{l}\text { Osteogenesis imperfecta, one type } \\
\text { Stickler }\end{array}$ & IDUA & Mucopolysaccharidosis I & SPTA & ytosis-2, sphero \\
\hline COL $2 A 1$ & Stickler & IFNA & Interferon, alpha - & SPTB & osis-3, spherocytosis 1 \\
\hline COL $3 A 1$ & Ehlers-Da & IFNG & Interferon, gamma & SRD5A1 & Pseudohermaphroditism, SRD5A1 \\
\hline CP & uloplasminaemia & IGF1 & & & \\
\hline CR2 & Infections, recurrent pyogenic & $\mathrm{IGH}$ & Immunoglobulin heavy chain - & STS & Ichthyosis, $\mathrm{s}$ \\
\hline CRYG1 & Cataract, Coppock-like & IL2 & Immunodeficiency, severe combined & TAT & Tyrosinaemia II \\
\hline $\mathrm{CSH} 1$ & Placental lactogen - & INS & tus, rare form, MODY & TCN2 & Anaemia, macrocytic (TCN2-) \\
\hline CYBB & Granulomatous, chronic $\mathrm{X}$ linked & INSR & Leprechaunism & TDF & Gonadal dysgenesis, $\mathrm{XY}$ type \\
\hline CYP11A & Lipoid adrenal hyperplasia & ITGB2 & Leucocyte adhesion - & TF & Atransferrinaemia \\
\hline CYP11B1 & Adrenal hyperplasia IV & KIT & Albinism, partial & TG & Hypo \\
\hline CYP17 & Adrenal hyperplasia V & KIT & Piebaldism & THRA1 & Thyroid hormone unresponsiveness \\
\hline CYP19 & Gynaecomastia (aromatase + ) & $\mathrm{KLK} 3$ & Fletcher factor - & TP53 & Li-Fraumeni (familial cancer) \\
\hline CYP21 & Adrenal hyperplasia III & KRAS2 & Adenomatosis, colo & TPI1 & Anaemia, haemolytic (TPI-) \\
\hline CYP27 & Cerebrotendinous xanthomatosis & KRT1 & Epidermolysis bullosa simplex, & TPO & Thyroid hormone defect \\
\hline CYP2D & Debrisoquine sensitivity & & & TRY1 & \\
\hline DBH & Dopamine-beta-hydroxylase & & Epidermolysis bullosa simplex & TSHB & Hypothyroidism, non-goitrous, TSH- \\
\hline DES & Cardiomyopathy, one form & LCAT & Noru & TSHR & aresponsiveness \\
\hline DHFR & Anaemia, megaloblastic (DHFR-) & LDHA & Myoglobinuria, exertional (LDF & TTR & Amyloid neuropathy \\
\hline DIA1 & Methaemoglobinaemia, enzymopathic & LDLR & Hypercholesterolaemia, familial & TYR & Albinism, tyrosinase negative \\
\hline DMD & Duchenne muscular dystrophy & LHB & Pseudohermaphroditism, LH derived & ÜGT1Al & Crigler-Najjar, type I \\
\hline EDA & Ectodermal dysplasia, anhidrotic & LHRH & Hypogonadism, hypogonadotrophic & UROI & Porphyria, hepatoerythropoietic \\
\hline EL1 & Elliptocytosis-1 & LIPA & Wolman & WT1 & s tumour \\
\hline ENO1 & Enolase deficiency & LPL & Hyperlipoproteinaemia & $\mathrm{XPA}$ & Xeroderma pigmentosum IX \\
\hline
\end{tabular}


Table 2 Listing of pathological variants in presumptive mouse homologues of human disease loci. ${ }^{6910}$ See also table $1 \mathrm{~A}$ and B. McKusick's classification of human phenotypes as dominant $(D)$, recessive $(R)$, or sex linked $(X)$ is given in parentheses after locus symbol

\begin{tabular}{|c|c|c|c|c|}
\hline \multicolumn{2}{|l|}{ Locus symbol } & \multicolumn{2}{|l|}{ Name of disease/mutant } & \multirow[t]{2}{*}{ Phenotypic effects in mice } \\
\hline Human & Mouse & Human & Mouse & \\
\hline $\begin{array}{l}\text { AN2(D)* }=\text { PAX6 } \\
\text { ANK1(D)* } \\
\text { APC(D) } \\
\text { APOB(D) }\end{array}$ & $\begin{array}{l}\text { Sey } \\
\text { nb } \\
\text { Min } \\
\text { Apob }\end{array}$ & $\begin{array}{l}\text { Aniridia-2 } \\
\text { Spherocytosis-2 } \\
\text { Polyposis coli, adenomatous } \\
\text { Hypobetalipoproteinaemia }\end{array}$ & $\begin{array}{l}\text { Small eye } \\
\text { Normoblastic anaemia } \\
\text { Multiple intestinal neoplasia } \\
\text { Apob deficient }\end{array}$ & $\begin{array}{l}\text { Small eyes, colobomata, homozygous lethal } \\
\text { Jaundiced young, splenomegaly etc, gallstones } \\
\text { Adenomata along intestinal tract } \\
\text { Decreased concentrations of lipoproteins, } \\
\text { cholesterol. Some with hydro- and } \\
\text { exencephalus }\end{array}$ \\
\hline $\operatorname{AR}(X)^{*}$ & $T f m$ & Testicular feminisation & Testicular feminisation & $\begin{array}{l}\text { Hemizygous males look female with minute } \\
\text { testes, androgen insensitivity }\end{array}$ \\
\hline $\begin{array}{l}\text { C5(D)* } \\
\text { CAT(D)* } \\
\text { CDPX2(X) } \\
\text { CFTR(R) } \\
\text { CMT1A(D) } \\
\text { COL1A2(R) } \\
\text { DMD }(X)^{*+}\end{array}$ & $\begin{array}{l}\text { Hc } \\
\text { Cas-1 } \\
\text { Bpa } \\
\text { Cftr } \\
\text { Tr } \\
\text { oim } \\
\text { mdx }\end{array}$ & $\begin{array}{l}\text { Lupus C5, predisposing } \\
\text { Acatalasaemia } \\
\text { Chondrodysplasia punctata, dominant } \\
\text { Cystic fibrosis } \\
\text { Charcot-Marie-Tooth neuropathy } \\
\text { Osteogenesis imperfecta } \\
\text { Duchenne muscular dystrophy }\end{array}$ & $\begin{array}{l}\text { Haemolytic complement null } \\
\text { Acatalasaemia } \\
\text { Bare patches } \\
\text { Cftr deficient } \\
\text { Trembler } \\
\text { Osteogenesis imperfecta } \\
\text { Muscular dystrophy }\end{array}$ & $\begin{array}{l}\text { Lowered resistance to infection } \\
\text { Increased susceptibility to liver tumours } \\
\text { Skin and skeletal lesions, hemizygous lethal } \\
\text { Intestinal obstruction, homozygous lethal } \\
\text { Tremor, convulsions, defective myelination } \\
\text { Multiple fractures, bone thinning, etc } \\
\text { Tremors, incoordination in old mice, muscle } \\
\text { fibre degeneration }\end{array}$ \\
\hline $\begin{array}{l}\operatorname{EDA}(X) \\
\operatorname{EPB} 42(D)\end{array}$ & $\begin{array}{l}T a \\
p a\end{array}$ & $\begin{array}{l}\text { Ectodermal dysplasia, anhidrotic } \\
\text { Spherocytosis }\end{array}$ & $\begin{array}{l}\text { Tabby } \\
\text { Pallid }\end{array}$ & $\begin{array}{l}\text { Defective teeth, skin, hairs } \\
\text { Prolonged bleeding time, depigmentation, } \\
\text { inner ear defects }\end{array}$ \\
\hline $\begin{array}{l}\mathrm{FECH}(\mathrm{D})^{*} \\
\mathrm{GALC}(\mathrm{R})^{*}\end{array}$ & $\begin{array}{l}\text { Fech } \\
\text { twi }\end{array}$ & $\begin{array}{l}\text { Protoporphyria, erythropoietic } \\
\text { Krabbe }\end{array}$ & $\begin{array}{l}\text { Ferrochelatase deficient } \\
\text { Twitcher }\end{array}$ & $\begin{array}{l}\text { Anaemia, photosensitivity, liver disease } \\
\text { Tremor, wasting, early death, psychosine } \\
\text { accumulation }\end{array}$ \\
\hline GBA(R)* & $G b a$ & Gaucher & Gba deficient & $\begin{array}{l}\text { Homozygous lethality, lysosomal storage of } \\
\text { glucocerebroside }\end{array}$ \\
\hline $\begin{array}{l}\text { GCPS(D) = GLI3 } \\
\text { GUSB(R)* } \\
\text { GY(X) }\end{array}$ & $\begin{array}{l}X t \\
\text { gus } \\
\text { Gy }\end{array}$ & $\begin{array}{l}\text { Greig cephalopolysyndactyly } \\
\text { Mucopolysaccharidosis VII } \\
\text { Hypophosphataemia with deafness }\end{array}$ & $\begin{array}{l}\text { Extra toes } \\
\text { Mucopolysaccharidosis VII } \\
\text { Gyro, phosphate transport defect }\end{array}$ & $\begin{array}{l}\text { Polydactyly etc, homozygous lethality } \\
\text { Small, male sterile, lack of adipose tissue } \\
\text { Rickets, inner ear anomalies, hemizygous } \\
\text { sterility }\end{array}$ \\
\hline $\begin{array}{l}\operatorname{HAL}(R) \\
\operatorname{HBA1}(\mathrm{D})^{*} \\
\operatorname{HBB}(\mathrm{D}) \\
\operatorname{HYP}(\mathrm{X})\end{array}$ & $\begin{array}{l}\text { his } \\
\text { Hba } \\
\text { Hbb } \\
\text { Hyp }\end{array}$ & $\begin{array}{l}\text { Histidinaemia } \\
\text { Thalassaemia, alpha } \\
\text { Thalassaemia, beta } \\
\text { Hypophosphataemia }\end{array}$ & $\begin{array}{l}\text { Histidinaemia } \\
\text { Thalassaemia, alpha } \\
\text { Thalassaemia, beta, polycythaemia } \\
\text { Hypophosphataemia, phosphate } \\
\text { transport defect }\end{array}$ & $\begin{array}{l}\text { Balance defect } \\
\text { Thalassaemia, homozygous lethal } \\
\text { Thalassaemia, polycythaemia } \\
\text { Skeletal changes like rickets }\end{array}$ \\
\hline $\begin{array}{l}\text { KIT(D) } \\
\text { LHRH(D)* } \\
=\text { GNRH }\end{array}$ & $\begin{array}{l}W \\
h p g\end{array}$ & $\begin{array}{l}\text { Piebaldism } \\
\text { Hypogonadism, hypogonadotrophic }\end{array}$ & $\begin{array}{l}\text { Dominant spotting } \\
\text { Hypogonadal }\end{array}$ & $\begin{array}{l}\text { White spotting, macrocytic anaemia, sterility } \\
\text { Underdeveloped reproductive tracts }\end{array}$ \\
\hline $\operatorname{MNK}(\mathrm{X})$ & Mo & Menkes kinky hair disease & Mottled, copper transport defect & $\begin{array}{l}\text { Defective collagen, keratin, pigmentation, and } \\
\text { behaviour; some alleles male lethal }\end{array}$ \\
\hline $\begin{array}{l}\text { NHS(X) } \\
\text { OCA2(R) }\end{array}$ & $\begin{array}{l}X c a t \\
p\end{array}$ & $\begin{array}{l}\text { Nance-Horan cataract-dental syndrome } \\
\text { Albinism, oculocutaneous type } 2\end{array}$ & $\begin{array}{l}\text { X linked cataract } \\
\text { Pink eyed dilution }\end{array}$ & $\begin{array}{l}\text { Total lens opacity in hemi/homozygote } \\
\text { Homozygotes with much reduced } \\
\text { pigmentation, ocular albinism in } p\end{array}$ \\
\hline OPD1(X) & $p t d$ & Otopalatodigital & Palate-tail-digits anomaly & $\begin{array}{l}\text { Frequent hemizygous lethality with cleft } \\
\text { palate; survivors with crooked tail, } \\
\text { polydactyly, etc }\end{array}$ \\
\hline OTC $(\mathrm{X})^{*}$ & $s p f$ & Ornithine transcarbamylase deficiency & Sparse fur & $\begin{array}{l}\text { Small, wrinkled skin, lack of hair, bladder } \\
\text { stones }\end{array}$ \\
\hline $\begin{array}{l}\operatorname{PAH}(\mathrm{R}) \\
\operatorname{PIT} 1(\mathrm{D})^{*} \\
\operatorname{PLP}(\mathrm{X})^{*} \\
\operatorname{RB} 1(\mathrm{D})\end{array}$ & $\begin{array}{l}P a h \\
d w \\
j p \\
R b-1\end{array}$ & $\begin{array}{l}\text { Phenylketonuria } \\
\text { Hypopituitarism } \\
\text { Pelizaeus-Merzbacher } \\
\text { Retinoblastoma }\end{array}$ & $\begin{array}{l}\text { Hyperphenylalaninemia } \\
\text { Dwarf } \\
\text { Jimpy } \\
R b-1 \text { deficient }\end{array}$ & $\begin{array}{l}\text { Homozygotes with hyperphenylalaninemia } \\
\text { Homozygotes small, sterile } \\
\text { Lethal, convulsions, myelin deficiency, etc } \\
\text { Heterozygotes associated with pituitary } \\
\text { tumours. Homozygotes lethal in utero }\end{array}$ \\
\hline $\begin{array}{l}\text { RDS(D) } \\
\text { SMPD1 } \\
=\text { NPD }\end{array}$ & $\begin{array}{l}r d s \\
s p m\end{array}$ & $\begin{array}{l}\text { Retinal degeneration, slow } \\
\text { Niemann-Pick disease }\end{array}$ & $\begin{array}{l}\text { Retinal degeneration, slow } \\
\text { Sphingomyelinosis }\end{array}$ & $\begin{array}{l}\text { Early onset retinal degeneration } \\
\text { Tremor, ataxia, death. Foam cells invade } \\
\text { liver, spleen. Purkinje cell depletion }\end{array}$ \\
\hline $\begin{array}{l}\text { SPTA1(D)* } \\
\text { SPTB(D)* } \\
\text { TG(D)** } \\
\text { TYR(R)* } \\
\text { WS1, WS3(D) } \\
=\text { PAX3 }\end{array}$ & $\begin{array}{l}s p h \\
j a_{+}^{+} \\
\operatorname{cog}{ }_{+}^{+} \\
c \\
S p(\operatorname{Pax}-3)\end{array}$ & $\begin{array}{l}\text { Elliptocytosis-2, spherocytosis-3 } \\
\text { Elliptocytosis-3, spherocytosis-1 } \\
\text { Hypothyroidism, goitrous } \\
\text { Albinism, tyrosinase negative } \\
\text { Waardenburg I and III }\end{array}$ & $\begin{array}{l}\text { Spherocytosis } \\
\text { Jaundiced } \\
\text { Congenital goitre } \\
\text { Albinism } \\
\text { Splotch }\end{array}$ & $\begin{array}{l}\text { Lethal spherocytic anaemia, no alpha spectrin } \\
\text { Severe microcytic anaemia, no beta spectrin } \\
\text { Small, enlarged thyroid } \\
\text { Absence of melanin, defective vision } \\
\text { Depigmentation, homozygous lethal with } \\
\text { neural tube defects }\end{array}$ \\
\hline
\end{tabular}

* Gene product absent or greatly reduced in pathological variants of both species.

† Homology based on absence of dystrophin in both DMD and $m d x$ variants ${ }^{6970}$ $\ddagger j a$ is thought to be a mutant at the $S p n b-1$ locus, homologous with SPTB, but this has yet to be confirmed. The same situation applies to $c o g$ and the Tgn locus,
homologous with human TG.

homologies, based mainly on phenotypic resemblances, have been omitted from these listings, for example, those between human WAS (Wiskott-Aldrich syndrome) and mouse $s f,{ }^{64}$ also IP (incontinentia pigmenti) and mouse $T d$ (tattered). ${ }^{65}$ However, the findings of Laval and Boyd ${ }^{66}$ have made these homologies more likely. Homology between the $\mathrm{X}$ linked agammaglobulinaemia locus (AGMX1) and $\mathrm{X}$ linked immune deficiency (xid) also needs clarification, as there are several human $\mathrm{X}$ linked immunodeficiencies. However, the $\mathrm{X}$ linked loci for human otopalatodigital syndrome (OPD1) and mouse palate-tail-digits anomaly ( $p t d$ ) have been included in the tables because of their unique and similar phenotypes and equivalent position on the map. ${ }^{434}$

\section{Chromosome maps of disease homologies}

Fig 1 is a synthesis of the data on chromosomal locations of disease genes (given in table 1 ) and of their mouse homologues, arranged in order of human chromosomes. Chromosomal locations of mouse homologues are shown under the human map, so as to indicate conserved segments. These can be used to predict the likely position in one species of a disease gene located to a conserved segment in the other. Since the mouse locus positions of fig 1 are arranged in order of increasing distance from the centromere, the slope of the result (if discernible) indicates whether orientations with respect to the centromere are the same in both species (as in human chromosome $1 \mathrm{p}$ and 

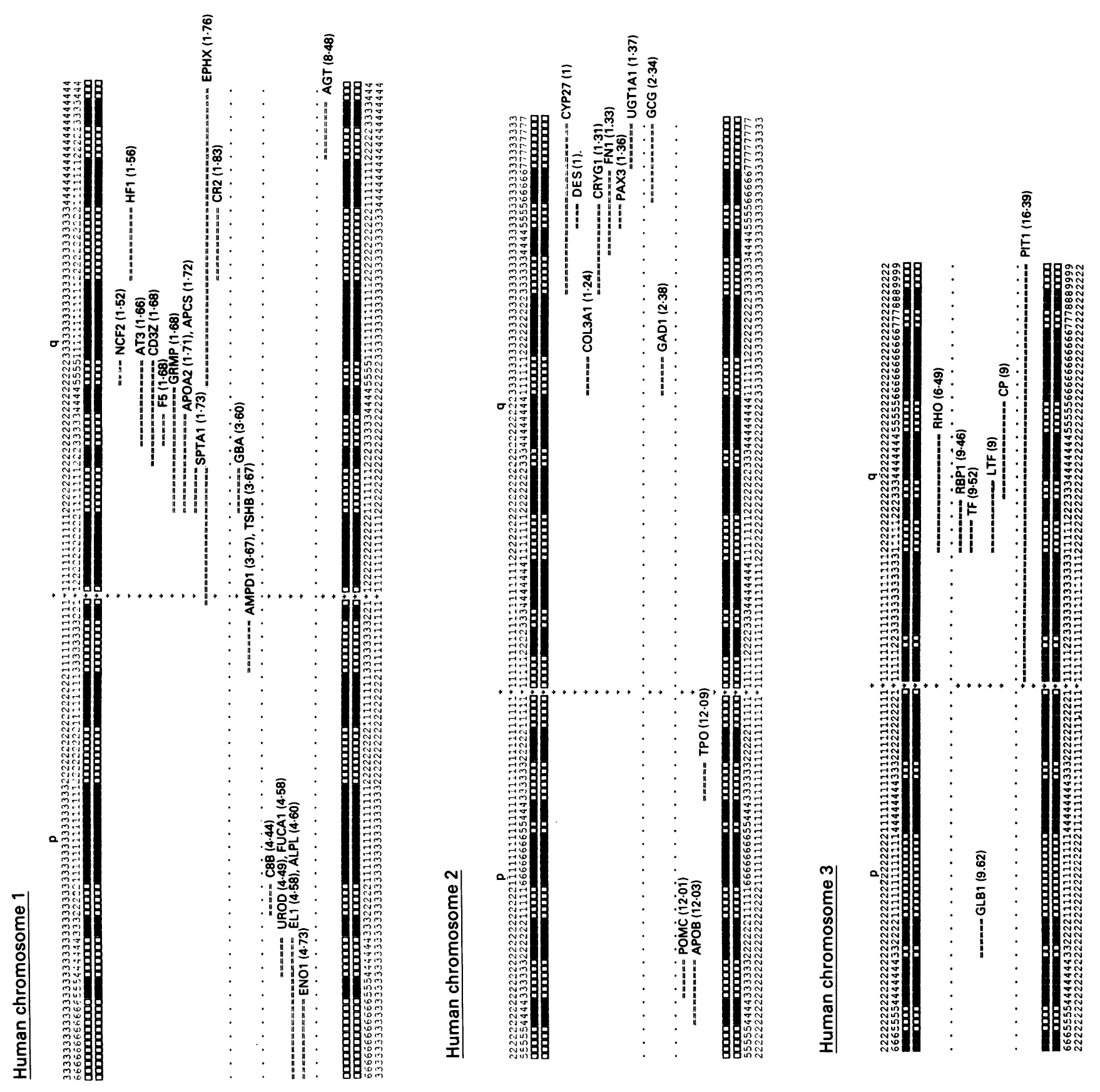

Figure 1 Positions of hereditary disease homologues on human and mouse chromosomes. Horizontal diagrams of banded human chromosomes are shown above and below, with $p$ and $q$ positions read vertically. Sandwiched between them are shown the band positions of homologous loci (indicated by their human gene symbols) by means of parallel lines under the human bands concerned, as well as chromosomal and regional locations (in terms of cM from the centromere) of homologues on the mouse map in parentheses. If only the chromosome number is shown the mouse gene has not been regionally located. Asterisks show centromere positions on the human chromosomes while horizontal dotted lines separate mouse loci on different chromosomes. 

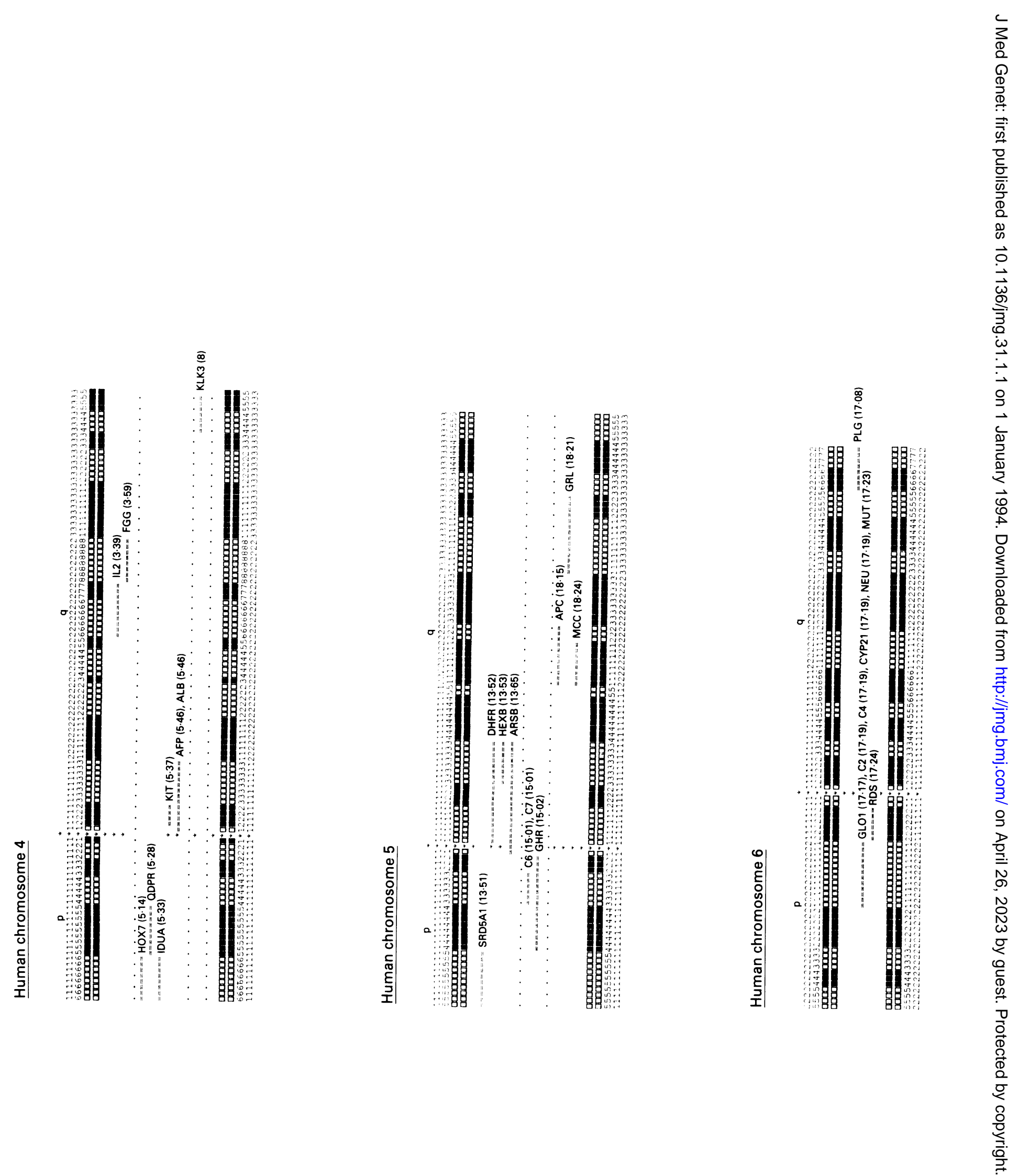

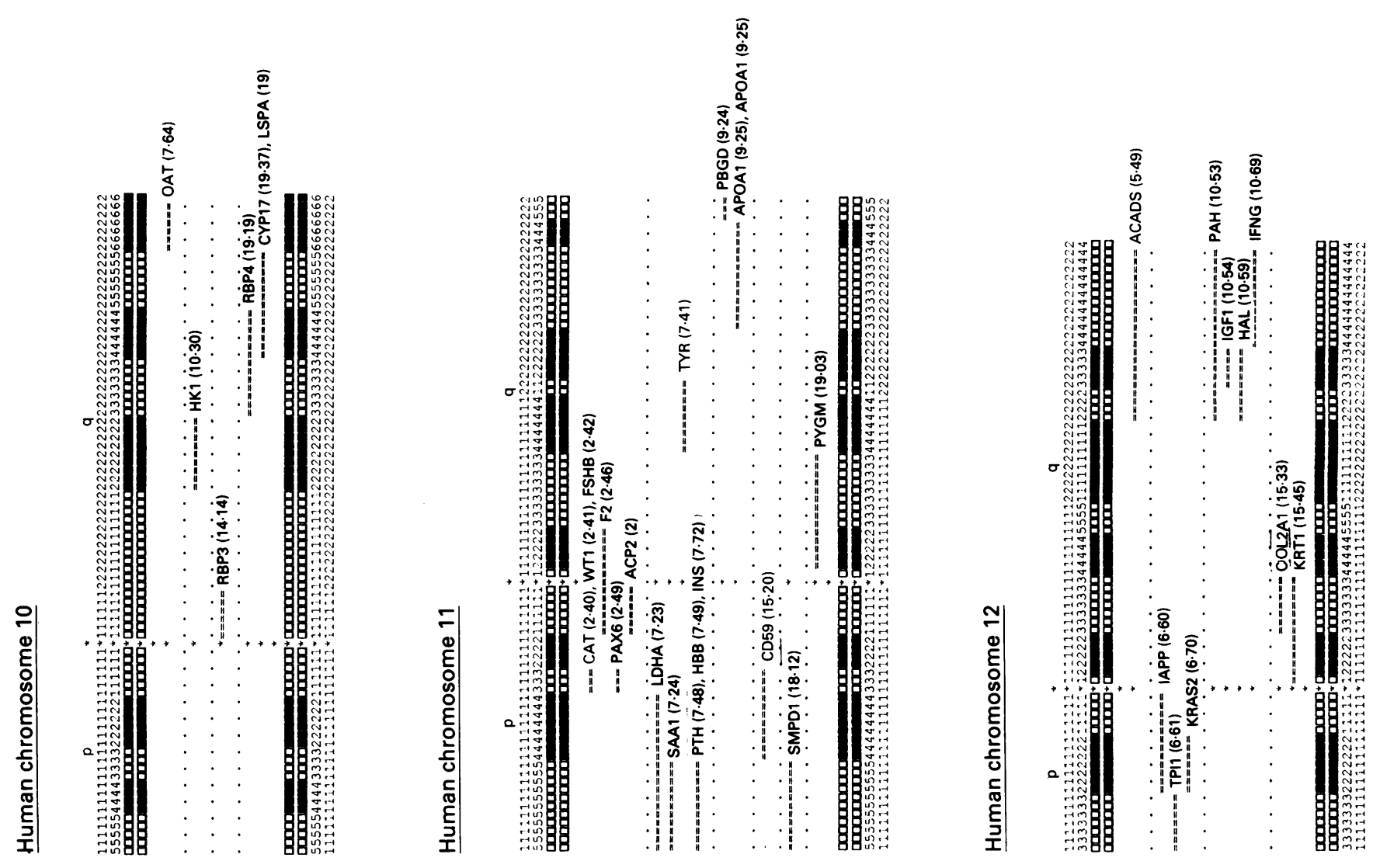

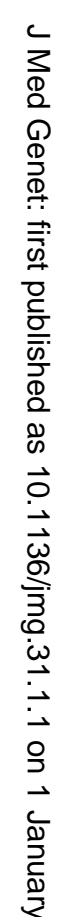
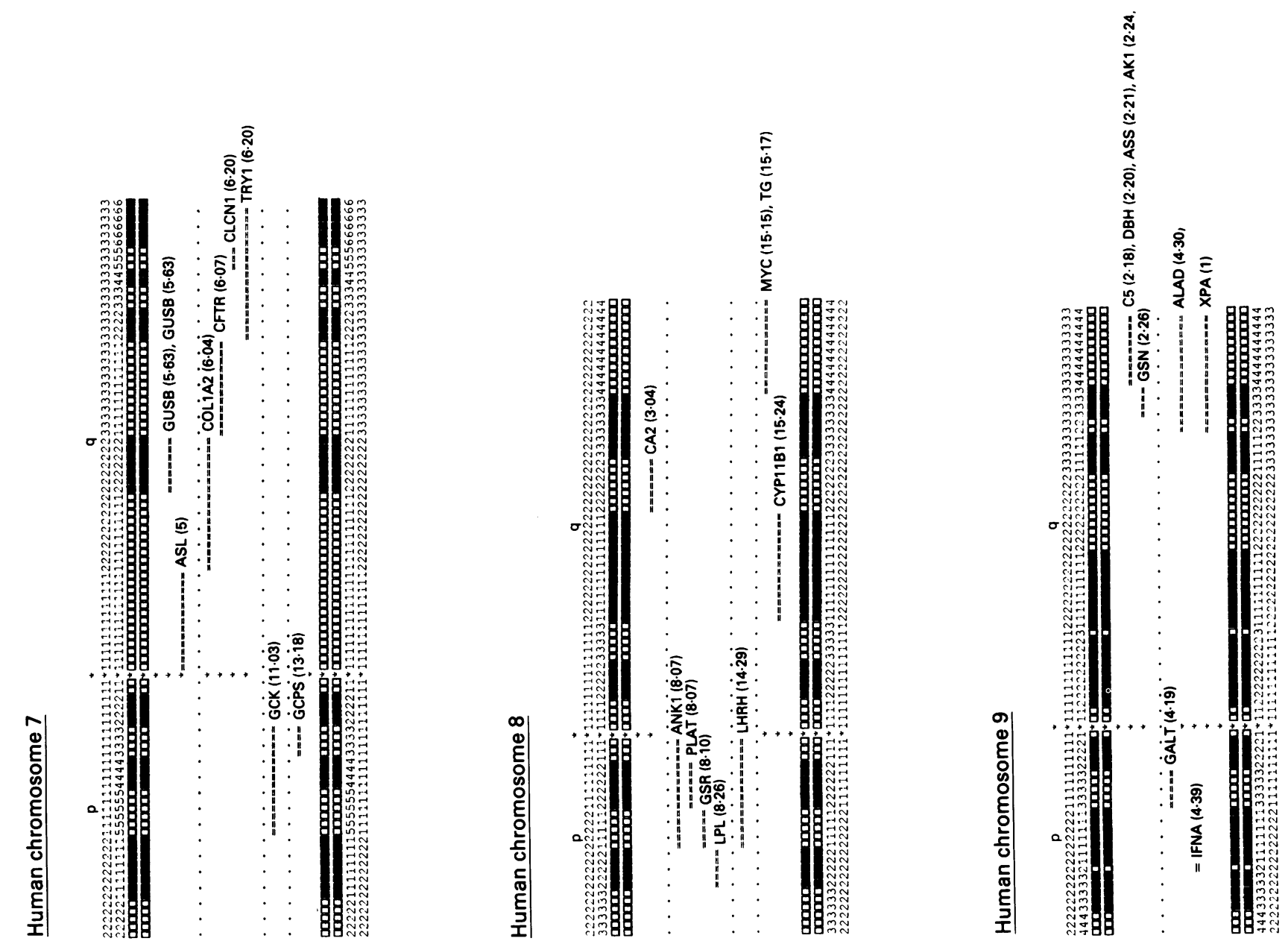

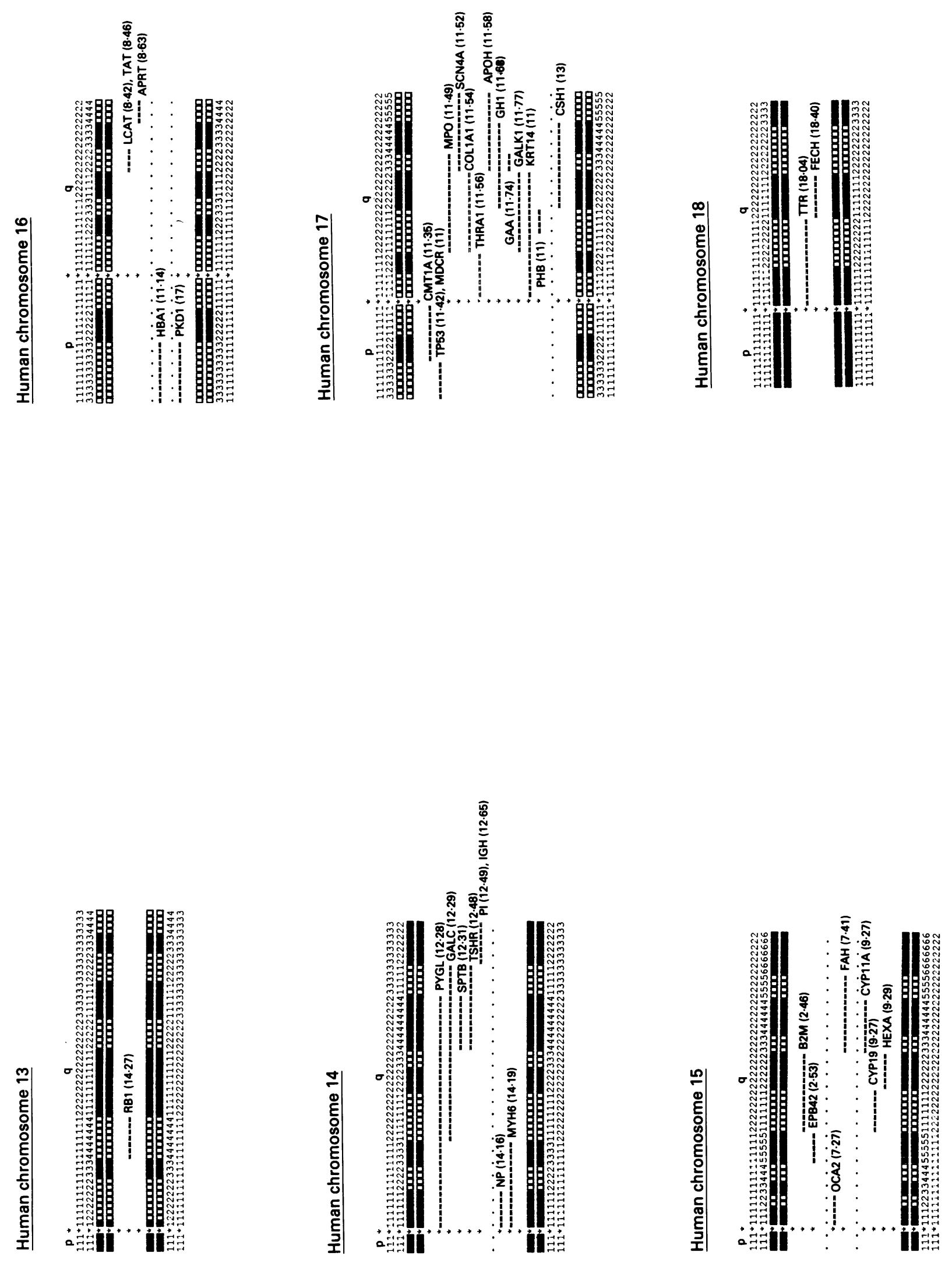

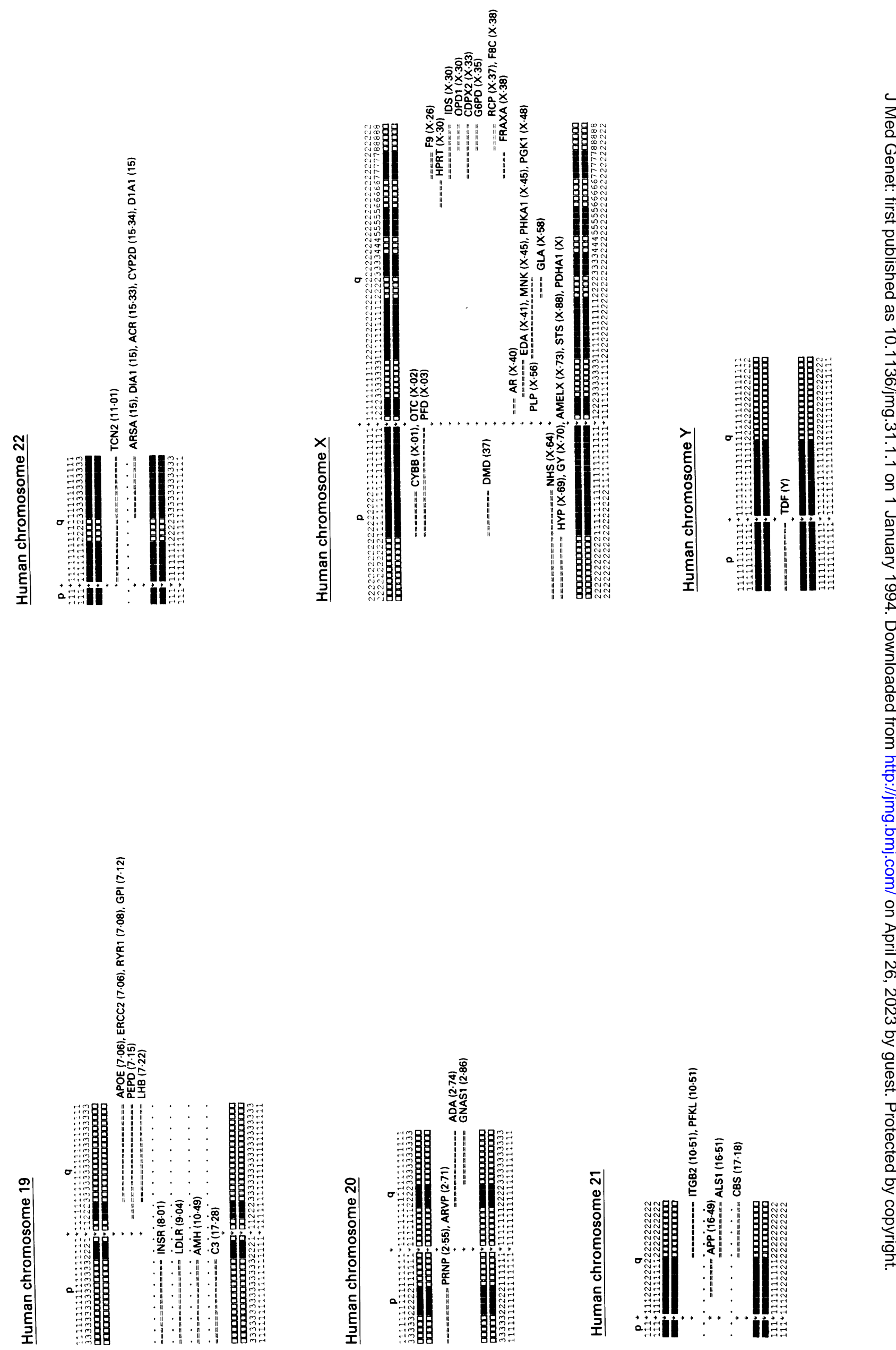


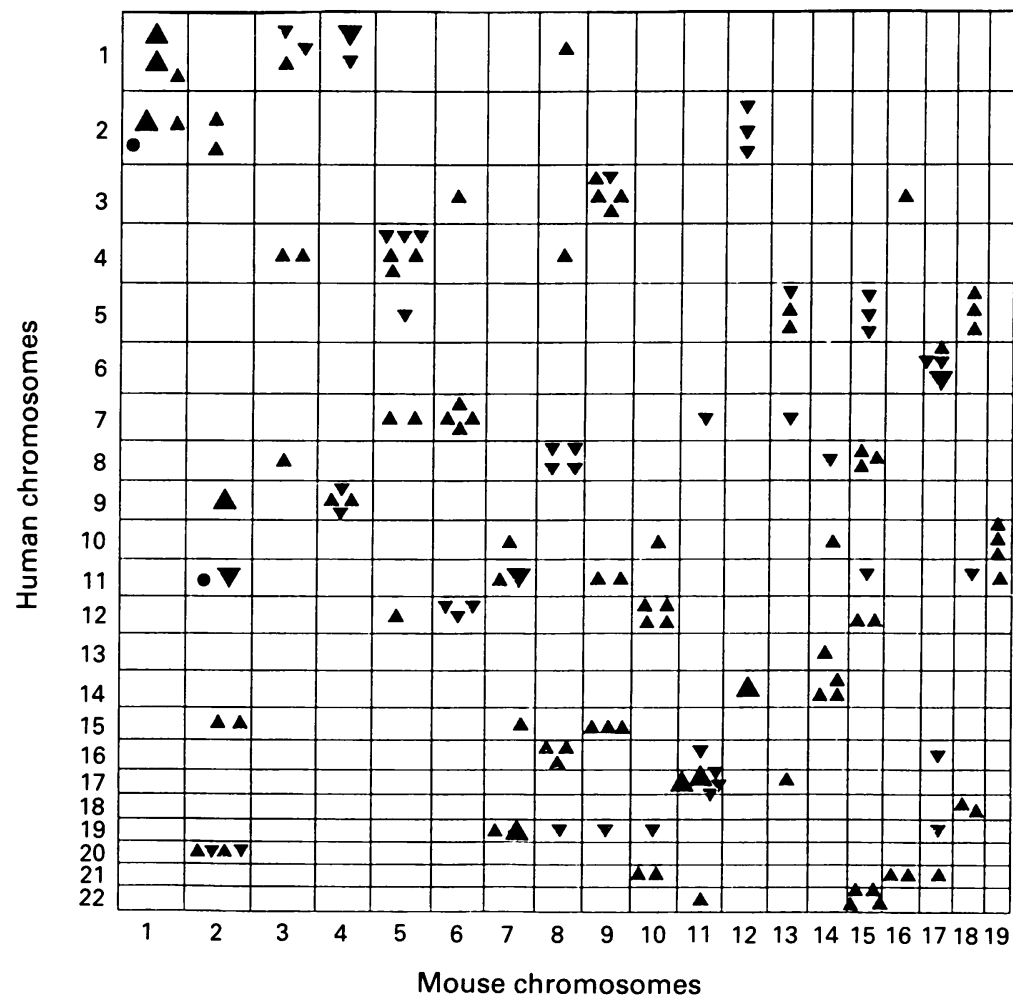

Figure 2 Oxford grid $^{67}$ which shows numbers of loci associated with hereditary disease which have been assigned to different pairs of human and mouse autosomes. Small triangles refer to individual loci, large triangles to groups of five. Where triangles poin downwards loci are in the short arm $(p)$, where upwards they are in $q$. Small circles represent a single locus unassigned to $p$ or $q$.

mouse 4) or opposite (as in human 1q and mouse 1). However, this point of evolutionary importance can be analysed with greater precision by use of the whole database (now comprising more than 900 pairs of assignments) rather than just the disease homologies, so is not considered further here.

\section{Oxford grid}

The Oxford grid $^{67}$ is designed to show the distribution of homologous loci and conserved segments among human and mouse autosomal arms. In the grid for all the assigned $\operatorname{loci}^{46}$ there is a general tendency for conserved regions to be found in chromosomes of similar relative size in the two species. This same tendency is found in the present grid (fig 2) for loci associated with hereditary diseases, since entries around the top-left to bottom-right diagonal are much more numerous than around the opposite diagonal. Homologous disease loci have been assigned on all human and mouse chromosomes, but human 13 is only represented once and human 18 twice. The $\mathrm{X}$ chromosome has more homologous disease loci than any others $(12 \%$ of the total) with human chromosomes $1(10 \%)$ and 11 $(9 \%)$ next. However, when all known humanmouse assignments are considered, human chromosome 1 has $68 \%$ more homologous loci than chromosome 11 .

\section{Nature of variation in mouse homologues}

We list 214 loci associated with human hereditary disease which have homologues located in the mouse. These should provide useful and valid mouse models for such diseases, once suitable mutants have been obtained.

For 32 of the mouse loci $(15 \%)$ no variants have been reported. There are 143 loci $(67 \%)$ associated with restriction fragment length variants, ${ }^{68}$ much used in mapping, but pathological variants have been reported so far from only $42(20 \%)$. These are marked with an asterisk in table $1 \mathrm{~A}$ and their characteristics are summarised in table 2 . They include examples of the successful production of pathological variants by targeted mutagenesis, such as the mouse models for cystic fibrosis (CFTR), ${ }^{71} 72$ for Gaucher disease (GBA), ${ }^{73}$ and for retinoblastoma (RB1). ${ }^{7475}$ Non-pathological variants other than RFLVs are known from 49 loci $(23 \%)$.

Homologies given in table 2 are based mainly on molecular and other biochemical criteria, apart from certain $\mathrm{X}$ linked loci (for example, human CDPX2, EDA, NHS) where they are based on phenotypic resemblance and expected location. Mouse symbols are as given in the standard listing ${ }^{10}$ but some alternatives, based on recent research throwing light on homology, are also given in parentheses. At several mouse loci multiple pathological alleles are known; only the most relevant one (or two in the case of $\mathrm{Hbb}$ ) are given in table 2 . McKusick $^{6}$ tabulates human phenotypes under autosomal dominant, autosomal recessive, and $\mathrm{X}$ linked; these are indicated in table 2 . For the mouse dominants, heterozygous effects are indicated in the table although homozygous ones (often lethality) may also be shown. For mouse recessives, homozygous effects are shown and both hemi- and heterozygous ones as a rule with the $\mathrm{X}$ linked variants. From a comparative point of view the most useful homologies are those in which the pathological effects seem to result from lack of the same gene product, for example, inactivation of the same enzyme in both species. The basis for homology has been marked with an asterisk in table 2 where this appears to be the case. It should be noted, however, that if the enzyme deficiency is the result of a chromosome deletion involving the gene concerned (as may frequently happen with radiation induced mutations), adjacent loci will often be affected also.

Among the 49 loci for which only nonpathological variants other than RFLVs have been described in the mouse are those associated with Fabry disease (GLA), gangliosidosis (GLB1), haemolytic anaemia resulting from G6PD deficiency (G6PD), Lesch-Nyhan disease (HPRT), Creutzfeldt-Jakob disease (PRNP), and X linked ichthyosis (STS). In general, these variants determine different forms of the enzyme concerned (often found in different mouse strains, races, or species) rather than enzyme deficiencies. An exception is the HPRT homology. A mouse mutant cell with loss of HPRT activity was selected in cultured embryonic stem (ES) cells and then incorporated into embryos to give mouse chimeras, from which mutant mice having the 
same genetic defect as Lesch-Nyhan patients were generated. ${ }^{7677}$ These were viable and apparently normal at birth and still appeared normal on later examination although they had abnormal dopamine levels, as expected with HPRT deficiency. It has now been reported ${ }^{78}$ that if $H$ prt deficient mice are given an APRT inhibitor they develop a Lesch-Nyhan type of self-injurious behaviour. Thus, mice seem more reliant on APRT than HPRT for their purine salvage, in contrast to humans.

Thus HPRT deficiency cannot be included among the pathological variants of the mouse, despite its severe effects in human hemizygotes. Another locus with contrasting effects in human and mouse deficiencies is that for Duchenne muscular dystrophy (DMD). This has been included among the mouse pathological variants (table 2) because affected mice develop tremors and mild incoordination when 'old', ${ }^{79}$ but effects in human victims of this disease are much more severe and do not involve incoordination beyond that secondary to weakness.

The most appropriate comparisons of pathological effects at human and mouse homologous loci are those between those having the same mutant gene dosage, whether homozygotes, hemizygotes, or heterozygotes. A problem arises with some recessive pathological variants in the mouse since the nature of a mutant homozygote may be unknown at the homologous human locus. One probable example is myelin basic protein (MBP) deficiency, which leads to the shiverer (shi) condition in mice, with a much shortened lifespan, violent shivering, and locomotor difficulties. ${ }^{9}$ Heterozygotes have normal behaviour but only half the normal amount of MBP. Effects of human homozygosity for MBP deficiency seem to be unknown. ${ }^{6}$ Another example involves colony stimulating factor 1 (CSF1). This protein gene is absent in the macrophage deficient osteopetrotic $(o p / o p)$ mouse, ${ }^{80}$ but the phenotype of human homozygotes for CSF1 deficiency is unknown. ${ }^{6}$

In general, scrutiny of table 2 together with information on the relevant human homologues $^{6}$ suggests that effects of pathological mutants are similar in both species. Of course this would be expected for those loci for which homologies have been postulated mainly on the basis of phenotypic effects (as well as appropriate chromosomal location), but it also seems to be true for those in which the homology is based on knowledge of proteins or DNA sequences involved.

\section{Positional predictions for loci without known homologies}

Many human or mouse pathological loci have been mapped in the one species but are unknown in the other. However, our knowledge of conserved regions in the two species is now so extensive that it is often possible to predict the likely map position of the undiscovered human or mouse locus from its known position in the other species, thus facilitating any search for the locus concerned.
A list of mouse loci, in alphabetical order of gene symbols, was scanned for pathological mutants. Data from the first 50 which had been regionally mapped but had as yet no human homologues (from asebia $a b$ to grey lethal $g l$ ) were analysed in relation to any neighbouring loci which had regionally assigned human homologues. It was found that for 26 of the loci (that is, over $50 \%$ ) the position of a human homologue could be confidently predicted because the mouse locus concerned lay within or very close to a known conserved region.

Even higher rates of prediction were obtained when a series of mapped human disease loci without known mouse homologues was analysed. Table 3 shows that for about $80 \%$ of these it was possible to predict regional locations of a mouse homologue with a fair degree of confidence. Only future mapping studies will show whether this confidence is justified.

Table 4 deals with the opposite situation, in which loci with pathological effects in the mouse have been located accurately but their possible human homologues have not. There are, of course, many other similar syndromes in the two species $^{8182}$ for which genetic information is more limited.

\section{Proto-oncogenes}

Another group of genes of considerable medical interest, besides those directly responsible for human hereditary disease, are the protooncogenes. An increasing number are now known to control various aspects of cell growth and differentiation when in their normal form. If, however, their essential functions are disrupted through mutation, structural change or other mechanisms, they may become oncogenic. Table 5 lists those proto-oncogene loci which have been mapped on both human and mouse chromosomes, as well as growth factor loci, many known to have oncogenic effects. These and other neoplasia related loci, including those for endogenous mouse mammary tumour and leukaemia viruses as well as genes controlling viral replication, viral and tumour specific antigens, etc, are listed by Kozak ${ }^{83}$ and by Roderick et al. ${ }^{84}$ The recently discovered family of Wnt genes is included as members are clearly oncogenic and seem to have an important role in intercellular signalling and other aspects of developmental regulation. ${ }^{85}$

Of the 69 loci listed here, 67 are in conserved segments of human-mouse homology, often of considerable length. The two apparent exceptions are REL and RET, but the human locations of both are regarded as provisional. ${ }^{6}$ The three oncogene loci JUNB, JUND, and MEL, together with the lymphoblastic leukaemia locus LYL1 and the insulin resistance gene INSR, form a medically interesting conserved (but disrupted) segment between human 19p and mouse 8 , with no other known members. ${ }^{86}$ The oncogene/growth factor group of loci seem to be fairly evenly spread over human and mouse chromosomes, with highest numbers on human 1 (7) and mouse 7 (9). 
Table 3 Probable location on mouse autosomes of homologues for mapped human disease loci

\begin{tabular}{|c|c|c|c|c|}
\hline \multirow[t]{2}{*}{ Name of disorder } & \multirow[t]{2}{*}{ Symbol } & \multirow[t]{2}{*}{ Human location } & \multicolumn{2}{|c|}{ Predicted mouse location } \\
\hline & & & $\begin{array}{l}\text { Chromosome } \\
\text { No }\end{array}$ & $\begin{array}{l}\text { Map units ( } c M \text { ) } \\
\text { from centromere }\end{array}$ \\
\hline $\begin{array}{l}\text { Acetyl-CoA carboxylase deficiency } \\
\text { Acoustic neuroma } \\
\text { Adrenal hyperplasia II } \\
\text { Alagille syndrome } \\
\text { Alcohol intolerance, acute } \\
\text { Alpha-1-antichymotrypsin deficiency } \\
\text { Angiodema } \\
\text { Ataxia telangiectasia } \\
\text { Basal cell naevus syndrome } \\
\text { Beckwith-Wiedemann syndrome } \\
\text { Cardiomyopathy, hypertrophic } \\
\text { Cerebrotendinous xanthomatosis } \\
\text { Deafness, low tone } \\
\text { Dentinogenesis imperfecta 1 } \\
\text { Diabetes mellitus, MODY type I } \\
\text { Diastrophic dysplasia } \\
\text { DiGeorge syndrome } \\
\text { Epidermolysis bullosa } \\
\text { Epilepsy, juvenile myoclonal } \\
\text { Fanconi anaemia } 1 \\
\text { Friedreich ataxia } \\
\text { Haemochromatosis } \\
\text { Huntington's disease } \\
\text { Langer-Giedion syndrome } \\
\text { Long QT syndrome } \\
\text { Marfan syndrome } \\
\text { Maroteaux-Lamy syndrome } \\
\text { Multiple endocrine neoplasia I } \\
\text { Muscular dystrophy, facioscapulohumeral } \\
\text { Muscular dystrophy, limb-girdle } \\
\text { Myotonic dystrophy } \\
\text { Nail-patella syndrome } \\
\text { Nemaline myopathy } \\
\text { Neurofibromatosis, von Recklinghausen } \\
\text { Oroticaciduria } \\
\text { Paraganglioma } \\
\text { Plasmin inhibitor deficiency } \\
\text { Polycystic ovarian disease } \\
\text { Prader-Willi syndrome } \\
\text { Rubinstein-Taybi syndrome } \\
\text { Sanfilippo syndrome } \\
\text { Smith-Magenis syndrome } \\
\text { Spinal muscular atrophy } \\
\text { Spinocerebellar ataxia 1 } \\
\text { Split hand/foot deformity type } 1 \\
\text { Torsion dystonia } \\
\text { Treacher-Collins mandibulofacial dysostosis } \\
\text { Trichorhinophalangeal syndrome } \\
\text { Tuberous sclerosis } 1 \\
\text { Usher syndrome, type 1 } \\
\text { van der Woude syndrome } \\
\text { von Hippel-Lindau syndrome } \\
\text { von Willebrand disease } \\
\text { Werner syndrome } \\
\text { Wilson disease } \\
\text { Xeroderma pigmentosum, group B } \\
\text { Zellweger syndrome } 1\end{array}$ & $\begin{array}{l}\text { ACAC } \\
\text { NF2 } \\
\text { HSDB3 } \\
\text { AGS } \\
\text { ALDH2 } \\
\text { AACT } \\
\text { C1NH } \\
\text { ATA } \\
\text { BCNS } \\
\text { BWS } \\
\text { MYH7 } \\
\text { CYP27 } \\
\text { LFHL1 } \\
\text { DGI1 } \\
\text { MODY1 } \\
\text { DTD } \\
\text { DGCR } \\
\text { COL7A1 } \\
\text { EJM1 } \\
\text { FA } \\
\text { FRDA } \\
\text { HFE } \\
\text { HD } \\
\text { LGCR } \\
\text { LQT } \\
\text { FBN1 } \\
\text { ARSB } \\
\text { MENI } \\
\text { FMD } \\
\text { LGMD1 } \\
\text { DM } \\
\text { NPS1 } \\
\text { NEM1 } \\
\text { NF1 } \\
\text { UMPS } \\
\text { PGL } \\
\text { PLI } \\
\text { EDH17B1 } \\
\text { PWCR } \\
\text { RSTS } \\
\text { GNS } \\
\text { SMCR } \\
\text { SMA } \\
\text { SCA1 } \\
\text { SHFD1 } \\
\text { DYT1 } \\
\text { TCOF1 } \\
\text { TRPS1 } \\
\text { TSC1 } \\
\text { USH1 } \\
\text { VWS } \\
\text { VHL } \\
\text { VWF } \\
\text { WRN } \\
\text { WND } \\
\text { ERCC3 } \\
\text { ZWS1 }\end{array}$ & $\begin{array}{l}\text { 17q21 } \\
22 \mathrm{q} 11.21-\mathrm{q} 13.1 \\
\text { 1p13.1 } \\
20 \mathrm{p} 11.2 \\
12 \mathrm{q} 24.2 \\
14 \mathrm{q} 32.1 \\
11 \mathrm{q} 11-\mathrm{q} 13.1 \\
11 \mathrm{q} 22-\mathrm{q} 23 \\
9 \mathrm{q} 31 \\
11 \mathrm{pter}-\mathrm{p} 15.4 \\
14 \mathrm{q} 12 \\
2 \mathrm{q} 33-\mathrm{qter} \\
5 \mathrm{q} 31-\mathrm{q} 33 \\
4 \mathrm{q} 13-\mathrm{q} 21 \\
20 \mathrm{q} 13 \\
5 \mathrm{q} 31-\mathrm{q} 34 \\
22 \mathrm{q} 11 \\
3 \mathrm{p} 21 \\
6 \mathrm{p} 21.3 \\
20 \mathrm{q} \\
9 \mathrm{q} 13-\mathrm{q} 21.1 \\
6 \mathrm{p} 21.3 \\
4 \mathrm{p} 16.3 \\
8 \mathrm{q} 24.11-\mathrm{q} 24.13 \\
11 \mathrm{p} 15.5 \\
15 \mathrm{q} 21.1 \\
5 \mathrm{q} 11-\mathrm{q} 13 \\
11 \mathrm{q} 13 \\
4 \mathrm{q} 34-\mathrm{qter} \\
5 \mathrm{q} 31.3-\mathrm{q} 33.5 \\
19 \mathrm{q} 13.2-\mathrm{q} 13.3 \\
9 \mathrm{q} 34 \\
1 \mathrm{q} 21-\mathrm{q} 23 \\
17 \mathrm{q} 11.2 \\
3 \mathrm{q} 13 \\
11 \mathrm{q} 22-\mathrm{q} 23 \\
17 \mathrm{pter}-\mathrm{p} 12 \\
17 \mathrm{q} 11-\mathrm{q} 12 \\
15 \mathrm{q} 11 \\
16 \mathrm{p} 13.3 \\
12 \mathrm{q} 14 \\
17 \mathrm{p} 11.2 \\
5 \mathrm{q} 12.2-\mathrm{q} 13.3 \\
6 \mathrm{p} 21.3-\mathrm{p} 21.2 \\
7 \mathrm{q} 21.2-\mathrm{q} 21.3 \\
9 \mathrm{q} 32-\mathrm{q} 34 \\
5 \mathrm{q} 31.3-\mathrm{q} 33.3 \\
8 \mathrm{q} 24.12 \\
9 \mathrm{q} 33-\mathrm{q} 34 \\
14 \mathrm{q} \\
1 \mathrm{q} 32 \\
3 \mathrm{p} 24-\mathrm{p} 25 \\
12 \mathrm{pter}-\mathrm{p} 12 \\
8 \mathrm{p} 12-\mathrm{p} 11 \\
13 \mathrm{q} 14-\mathrm{q} 21 \\
2 \mathrm{q} 21 \\
7 \mathrm{q} 11.23 \\
\end{array}$ & $\begin{array}{l}11 \\
15 \text { or } 16 \\
3 \\
2 \\
10 \\
12 \\
19 \\
9 \\
2 \text { or } 4 \\
7 \\
12 \\
1 \\
11 \\
4 \\
2 \\
11 \\
16 \\
9 \\
17 \\
2 \\
19 ? \\
17 \\
5 \\
15 \\
7 \\
2 \text { or } 9 \\
13 \\
19 \\
8 ? \\
11 \\
7 \\
2 \\
1 \\
11 \\
9 ? \\
9 \\
11 \\
11 \\
7 \\
16 \\
10 \\
11 \\
13 \\
17 \\
5 \\
2 \\
18 \\
15 \\
2 \\
12 \text { or } 14 \\
1 \\
6 \text { or } 14 \\
6 \\
8 \\
14 \\
2 \\
5 \text { or } 6\end{array}$ & $\begin{array}{l}49-62 \\
25-27 \text { or } 12-18 \\
63-67 \\
55-65 \\
56-70 \\
49-\text { ter } \\
\text { Cen-16 } \\
14-25 \\
10-30 \text { or } 25-35 \\
23-26 \\
20-31 \\
25-32 \\
23-30 \\
36-50 \\
74-\text { ter } \\
23-30 \\
12-18 \\
54-70 \\
17-23 \\
- \\
-17-23 \\
13-31 \\
15-28 \\
23-50 \\
51-56 \text { or } 26-27 \\
52-65 \\
\text { Cen-16 } \\
230 ? \\
23-30 \\
\text { Cen-22 } \\
14-26 \\
71-73 \\
44-50 \\
45-52 \\
14-25 \\
37-43 \\
44-50 \\
26-33 \\
\text { Cen-12 } \\
71-73 \\
37-43 \\
52-66 \\
17-25 \\
53-69 \\
14-26 \\
17-35 \\
15-28 \\
14-26 \\
-47-56 \\
35-45 \text { or cen-10 } \\
50-71 \\
5-10 \\
28-\text {-ter } \\
27-56 \\
- \\
\end{array}$ \\
\hline
\end{tabular}

Table 4 Genetically unassigned human syndromes suspected of homology with mouse genes of known regional location, thus allowing tentative predictions of likely human gene location

\begin{tabular}{|c|c|c|c|c|}
\hline \multirow[t]{2}{*}{ Name of human syndrome } & \multirow[t]{2}{*}{$M I M N o$} & \multirow[t]{2}{*}{ Mouse mutant(s) } & \multicolumn{2}{|l|}{ Locations } \\
\hline & & & Mouse & Human (predicted) \\
\hline Acromesomelic dysplasia & 201250 & Ulnaless $(U l)$ & 2.35 & $2 q 31-q 37$ \\
\hline Cenani-Lenz (syndactylism) & 212780 & Limb deformity $(l d)$ & 2.53 & $15 \mathrm{q} 15$ \\
\hline Chediak-Higashi (lysosomal) & 214500 & Beige $(b g)$ & 13.17 & $1 q 43 / 7 p$ \\
\hline Epilepsy, temporal lobe & - & Epilepsy $(E l-1)$ & 9.51 & $3 q 21$ \\
\hline Fraser (cryptophthalmos) & 219000 & $\begin{array}{l}\text { Blebs }(m y) \text { or } \\
\text { Blebbed }(b l)\end{array}$ & $\begin{array}{l}3.39 \text { or } \\
5.44\end{array}$ & $\begin{array}{l}4 q 26-q 27 \text { or } \\
4 q 11-q 13\end{array}$ \\
\hline $\begin{array}{l}\text { Fryns } \\
\text { Hermansky-Pudlak }\end{array}$ & 229850 & Short ear $(s e)$ & 9.38 & $6 \mathrm{p} 12 / 15 \mathrm{q}$ \\
\hline Hermansky-Pudlak & 203300 & $\begin{array}{l}\text { Cocoa (coa) or } \\
\text { pearl }(p e)\end{array}$ & $\begin{array}{l}3.07 \text { or } \\
13.62\end{array}$ & $8 q$ or $5 q$ \\
\hline Pituitary dwarfism III & 262600 & Miniature $(m n)$ & 15.26 & $22 \mathrm{q} 12 / 8 \mathrm{q} 24$ \\
\hline Osteopetrosis (Albers-Schonberg) & 259700 & Grey lethal $(g l)$ & 10.25 & $6 \mathrm{q} 21$ \\
\hline Restrictive dermopathy & 275210 & Pupoid fetus ( $p f)$ & 4.61 or & $1 \mathrm{p} 36$ or \\
\hline Situs inversus viscerum & 270100 & $\begin{array}{l}\text { or tight skin }(T s k) \\
\text { Situs inversus viscerum }(i v)\end{array}$ & $\begin{array}{r}2.56 \\
12.63\end{array}$ & $\begin{array}{l}2 q / 15 q / 20 p \\
14 q 32\end{array}$ \\
\hline Spondylocostal dysplasia & 277300 & Rachiterata $(r h)$ & 2.35 & $2 q 31-q 37$ \\
\hline
\end{tabular}

Their regional location shows no marked signs of a proximal or distal bias.

\section{Genomic imprinting}

In recent years it has been realised that the route of inheritance of a gene, that is, the parent of origin, can influence its phenotypic effects and expression in various tissues as well as those of any mutation which it carries. Normally, of course, an autosomal gene is inherited from both parents but a deletion of the locus concerned, or such phenomena as non-disjunction or meiotic segregation in translocation heterozygotes, can lead to transmission from one parent only, that is, to uniparental disomy or monosomy. For certain 
Table 5 Proto-oncogene (O) and growth factor (GF) homologies in human and mouse chromosomes

\begin{tabular}{|c|c|c|c|c|c|c|c|}
\hline \multicolumn{2}{|c|}{ Locus symbol } & \multirow[t]{2}{*}{ Name } & \multicolumn{2}{|c|}{ Human location } & \multicolumn{3}{|c|}{ Mouse location } \\
\hline Man & Mouse & & Chr & $G$ band & $C h r$ & $c M^{*}$ & $G$ band \\
\hline ABL1 & $A b l$ & Abelson leukaemia $\mathrm{O}$ & 9 & q34 & 2 & 21 & B \\
\hline ABL2 & Abll & ABL-like O & 1 & $\mathrm{q} 24-\mathrm{q} 25$ & 1 & 62 & C5-H3 \\
\hline AKT1 & $A k t$ & Murine thymoma viral $\mathrm{O}$ & 14 & $\mathrm{q} 32.3^{2}$ & 12 & 65 & F1-F2 \\
\hline ARAF1 & Araf & Raf related $\mathrm{O}$ & $\mathrm{x}$ & p11.4-p11.23 & $\mathbf{x}$ & 7 & A2-A3 \\
\hline EGF & $E g f$ & Epidermal GF & 4 & q25 & 3 & 78 & F3-H1 \\
\hline EGFR & Erbb & Epidermal GF receptor & 7 & p13-p12 & 11 & 8 & A1-A2 \\
\hline ERBB2 & $E r b b-2$ & Erythroblastosis B2 O & 17 & $\mathrm{q} 11.2-\mathrm{q} 12$ & 11 & 56 & D-E1 \\
\hline ETS1 & Ets -1 & E26 avian leukaemia 10 & 11 & q23.3 & 9 & 14 & Al-A4 \\
\hline ETS2 & Ets-2 & E26 avian leukaemia 20 & 21 & q22.3 & 16 & 57 & C3-C4 \\
\hline FES & Fes & Feline sarcoma $\mathrm{O}$ & 15 & q25-qter & 7 & 37 & D1-D3 \\
\hline FGF1 & Fgf-1 & Fibroblast GF 1, acidic & 5 & $\mathrm{q} 31.3-\mathrm{q} 33.2$ & 18 & 19 & C-D \\
\hline FGF2 & $F g f-2$ & Fibroblast GF 2, basic & 4 & $\mathrm{q} 26-\mathrm{q} 27$ & 3 & 18 & A2-B \\
\hline FGF3 & Fgf-3 & Fibroblast GF 3 (INT2 O) & 11 & q13 & 7 & 74 & F1-ter \\
\hline FGF4 & Fgf-4 & Fibroblast GF 4 (HSTF1 O) & 11 & $\mathrm{q} 13$ & 7 & 74 & F1-ter \\
\hline FGF5 & Fgf-5 & Fibroblast GF 5 & 4 & $\mathrm{q} 21$ & 5 & 50 & $\mathbf{F}$ \\
\hline FGF6 & Fgf-6 & Fibroblast GF 6 & 12 & p13 & 6 & 54 & F3-G1 \\
\hline FGFR1 & Fgfrl & Fibroblast $\mathrm{GF}$ receptor 1 & 8 & p12-p11.2 & 8 & 10 & A1-A4 \\
\hline FGR & Fgr & Gardner-Rasheed feline sarcoma $\mathrm{O}$ & 1 & p36.2-p36.1 & 4 & 62 & D3 \\
\hline FOS & Fos & FBJ osteosarcoma O & 14 & $\mathrm{q} 24.3-\mathrm{q} 31$ & 12 & 35 & Cen-F1 \\
\hline FYN & Fyn & FYN oncogene & 6 & $\mathrm{q} 21$ & 10 & 24 & Cen-B4 \\
\hline GLI & Gli & Glioblastoma O & 12 & q13.3-14.1 & 10 & 72 & D \\
\hline GLI3 & Gli-3 & Glioblastoma O 3 & 7 & p13 & 13 & 18 & A2 \\
\hline GRO1 & Mgsa & GRO1 O, melanoma growth stim activity & 4 & $\mathrm{q} 21$ & 5 & 45 & E2-F \\
\hline HRAS & Hras -1 & Harvey rat sarcoma $\mathrm{O}$ & 11 & p15.5 & 7 & 31 & C-D3 \\
\hline HS1 & His-1 & His-1 O & 2 & $\mathrm{q} 14-\mathrm{q} 21$ & 2 & 32 & \\
\hline IGF1 & $\operatorname{Igf}-1$ & Insulin-like GF 1 & 12 & q23 & 10 & 54 & C1-D1 \\
\hline IGF1R & Igflr & Insulin-like GF 1 receptor & 15 & q25-qter & 7 & 31 & C-D3 \\
\hline IGF2 & $\operatorname{lgf}-2$ & Insulin-like GF 2 & 11 & p15.5 & 7 & 72 & F1-ter \\
\hline IGF2R & $\operatorname{lgf} 2 r$ & Insulin-like GF 2 receptor & 6 & $\mathrm{q} 25-\mathrm{q} 27$ & 17 & 11 & A2-A3 \\
\hline INT4 & Int -4 & Mammary tumour virus integration site 40 & 17 & $\mathrm{q} 21-\mathrm{q} 22$ & 11 & 62 & E1-E2 \\
\hline JUN & fun & Avian sarcoma virus $\mathrm{O}$ & 1 & p32 & 4 & 40 & $\mathrm{C} 5-\mathrm{C} 7$ \\
\hline JUNB & funb & Avian sarcoma virus B O & 19 & $\mathrm{p} 13.2$ & 8 & 29 & C \\
\hline JUND & fund & Avian sarcoma virus $\mathrm{D} O$ & 19 & $\mathrm{p} 13.2$ & 8 & 22 & $\mathrm{C}$ \\
\hline KIT & Kit & Kit (Hardy-Zuckerman) O & 4 & $\mathrm{q} 11-\mathrm{q} 12$ & 5 & 37 & D-E2 \\
\hline KRAS2 & Kras-2 & Kirsten rat sarcoma 20 & 12 & p12.1 & 6 & 70 & F3-G3 \\
\hline LYN & Lyn & Yamaguchi sarcoma, viral related $\mathrm{O}$ & 8 & q13-qter & 4 & 6 & A1-A2 \\
\hline MAS1 & Mas & Mas O & 6 & $\mathrm{q} 24-\mathrm{q} 27$ & 17 & 8 & $\mathrm{~A} 2-\mathrm{A} 3$ \\
\hline MEL & Mel & $\mathrm{NK} 14$ derived transforming $\mathrm{O}$ & 19 & p13.2-cen & 8 & 30 & C \\
\hline MET & Met & Met O & 7 & q31 & 6 & 6 & Cen-B1 \\
\hline MGF & sl & Mast cell GF & 12 & q14.3-qter & 10 & 65 & D1 \\
\hline MOS & Mos & Moloney sarcoma $\mathrm{O}$ & 8 & q11 & 4 & 6 & A1-A2 \\
\hline MYB & $M y b$ & Avian myeloblastosis $\mathrm{O}$ & 6 & $\mathrm{q} 22-\mathrm{q} 23$ & 10 & 16 & Cen-B4 \\
\hline MYC & Myc & Myelocytomatosis $\mathrm{O}$ & 8 & $\mathrm{q} 4.1$ & 15 & 15 & D2-D3 \\
\hline MYCL1 & Lmyc-1 & Lung carcinoma, myc related $\mathrm{O}$ & 1 & p32 & 4 & 50 & C7-D1 \\
\hline MYCN & Nmyc-1 & Neuroblastoma, myc related $\mathrm{O}$ & 2 & p24.1 & 12 & 4 & Cen-F1 \\
\hline NGFB & $N g f b$ & Nerve beta GF & 1 & p13 & 3 & 67 & F3-H1 \\
\hline NGFG & Ngfg & Nerve gamma GF & 19 & - & 7 & 22 & C \\
\hline NGFR & Ngfr & Nerve growth factor receptor & 17 & $\mathrm{q} 21-\mathrm{q} 22$ & 11 & 54 & $\mathrm{D}$ \\
\hline NRAS & Nras & Neuroblastoma transforming $\mathrm{O}$ & 1 & p13 & 3 & 63 & D-H1 \\
\hline PDGFA & Pdgfa & Platelet derived GF alpha & 7 & p22 & 5 & 69 & $\mathrm{G}$ \\
\hline PDGFB & Pdgfb & Platelet derived GF beta & 22 & $\mathrm{q} 12.3-\mathrm{q} 13.1$ & 15 & 25 & $\mathbf{E}$ \\
\hline PDGFRA & Pdgfra & Platelet derived GF receptor alpha & 4 & $\mathrm{q} 11-\mathrm{q} 13$ & 5 & 37 & D-E2 \\
\hline PDGFRB & Pdgfrb & Platelet derived GF receptor beta & 5 & $q 33-q 35$ & 18 & 31 & \\
\hline PIM & Pim-1 & Proviral integration, $\mathrm{MCF}, \mathrm{O}$ & 6 & p21 & 17 & 17 & A3-B \\
\hline PVT1 & Pvt -1 & Plasmacytoma variant translocation $\mathrm{O}$ & 8 & $\mathrm{q} 24$ & 15 & 16 & D2-D3 \\
\hline RAF1 & Raf-1 & Murine leukaemia viral O & 3 & p25 & 6 & 45 & $\mathrm{C} 3$ \\
\hline REL & $\mathrm{Rel}$ & Reticuloendotheliosis O & 2 & $\mathrm{p} 13-\mathrm{p} 12$ & 11 & 12 & A1-B1 \\
\hline RET & Ret & Ret $\mathrm{O}$ & 10 & $\mathrm{q} 11.2$ & 6 & 46 & C3-F3 \\
\hline RRAS & Rras & Related ras viral $\mathrm{O}$ & 19 & q13.3-qter & 7 & 22 & $\mathrm{C}$ \\
\hline SEA & Sea & $\mathrm{S} 13$ avian erythroblastosis $\mathrm{O}$ & 11 & $\mathrm{q} 13$ & 19 & 5 & B \\
\hline SKI & $S_{k i}$ & Sloane-Kettering avian viral 0 & 1 & $\mathrm{q} 22-\mathrm{q} 24$ & 4 & 69 & D3-ter \\
\hline SRC & Src & Rous sarcoma $\mathrm{O}$ & 20 & $\mathrm{q} 12-\mathrm{q} 13.11$ & 2 & 71 & H1 \\
\hline TGFB1 & $T g f b-1$ & Transforming beta $1 \mathrm{GF}$ & 19 & $\mathrm{q} 13.1$ & 7 & 7 & Cen-A3 \\
\hline TGFB2 & $T g f b-2$ & Transforming beta $2 \mathrm{GF}$ & 1 & $\mathrm{q} 41$ & 1 & 79 & H5-ter \\
\hline TGFB3 & $T g f b-3$ & Transforming beta $3 \mathrm{GF}$ & 14 & $\mathrm{q} 24$ & 12 & 36 & Cen-F1 \\
\hline THRA1 & Erba & Thyroid hormone receptor $\mathrm{O}$ & 17 & $\mathrm{q} 11.2-\mathrm{q} 12$ & 11 & 56 & D-E1 \\
\hline WNT1 & $W n t-1$ & Wingless related integration site 1 & 12 & $\mathrm{q} 13$ & 15 & 41 & F1-F3 \\
\hline WNT2 & $W n t-2$ & Wingless related MMTV integration site 2 & 7 & q31 & 6 & 6 & Cen-B1 \\
\hline WNT3 & Wnt-3 & Wingless related MMTV integration site 3 & 17 & $\mathrm{q} 21-\mathrm{q} 22$ & 11 & 62 & E1-E2 \\
\hline
\end{tabular}

${ }^{*}$ Distance from centromere in centimorgans.

loci or chromosome regions uniparental inheritance has a detrimental effect, the nature and extent of which may depend on whether the inheritance is maternal or paternal. ${ }^{87}$ In addition, distortion of segregation ratios, with human examples in cystic fibrosis, diabetes, neural tube defects, and allergy pedigrees, ${ }^{88}$ may reflect a parent of origin effect. ${ }^{89}$

Two of the most convincing examples of imprinting among human conditions concern the Angelman (AS) and Prader-Willi syndromes (PWS) with different clinical phenotypes but both often involving deletions in 15q11-q13. However, the Angelman syndrome is associated with maternal origin of the deletion $^{9091}$ while the Prader-Willi syndrome is associated with its paternal origin..$^{92}$ This deletion is in a short region of conserved synteny between parts of human 15q and mouse $7 .{ }^{93}$ The latter chromosome has one imprinting region proximal to $G$ band $7 C$ and another distal to $7 E 1 .{ }^{94}$ The deleted region in AS/PWS seems homologous to a more central region of mouse 7, but recent evidence shows that this region too is implicated in the imprinting phenomenon. ${ }^{95}$ These two human syndromes also arise in the absence of deletions but associated with either iso- or heterodisomy of the maternal chromosome 15 (in PWS) ${ }^{96}$ or the paternal one (in AS) ${ }^{97}$ as would be expected if genomic imprinting is occurring in this region. It now seems likely that there are separate 
Table 6 Mapped human disease loci and chromosomal regions possibly involved in genomic imprinting ${ }^{8799-114}$ with homologous regions in the mouse. ${ }^{34} M, P=$ maternal or paternal inheritance when human anomaly is expressed. Where evidence for imprinting is described as 'slight' in last column, differential rates of recovery of maternal and paternal disomies have been reported ${ }^{89}$

\begin{tabular}{|c|c|c|c|c|c|}
\hline \multirow[t]{2}{*}{ Chromosome } & \multicolumn{3}{|l|}{ Human } & \multicolumn{2}{|l|}{ Mouse } \\
\hline & Disease/malformation & Locus symbol & Origin & Homologous region in $\operatorname{chr}(s)$ & Evidence for imprinting in these \\
\hline $\begin{array}{l}4 \mathrm{p} 16.3 \\
6 \mathrm{p} 21.3-21.2 \\
7\end{array}$ & $\begin{array}{l}\text { Huntington's (severe early onset form) } \\
\text { Spinocerebellar ataxia } \\
\text { Pre- and postnatal growth retardation }\end{array}$ & $\begin{array}{l}\text { HD } \\
\text { SCA1 } \\
-\end{array}$ & $\begin{array}{l}\mathbf{P} \\
\mathbf{P} \\
\text { Uniparental } \\
\text { disomy } \mathbf{M}\end{array}$ & $\begin{array}{l}5 \mathrm{~B}-\mathrm{F} \\
17 \\
2,5,6,11,13\end{array}$ & $\begin{array}{l}\text { Slight } \\
\text { Yes } \\
\text { Yes on } 2,6,11\end{array}$ \\
\hline $\begin{array}{l}9 \mathrm{q} 34-\mathrm{qter} \\
22 \mathrm{cen}-\mathrm{q} 11 \\
11 \mathrm{p} 15.5 \\
11 \mathrm{p} 15.5 \\
11 \mathrm{p} 13 \\
11 \mathrm{q} 23-\mathrm{qter} \\
13 \mathrm{q} 14.1-\mathrm{q} 14.2 \\
14 \\
14 \\
15 \mathrm{q} 11-\mathrm{q} 13\end{array}$ & $\begin{array}{l}\text { Chronic myeloid leukaemia } \\
\text { Embryonal rhabdomyosarcoma } \\
\text { Beckwith-Wiedemann } \\
\text { Wilms's tumour } \\
\text { Paraganglioma } \\
\text { Retinoblastoma 1 } \\
\text { Dysmorphism, mental defect } \\
\text { Short stature } \\
\text { Angelman }\end{array}$ & $\begin{array}{l}- \\
\text { RMS } \\
\text { BWS } \\
\text { WT1 } \\
\text { PGL } \\
\text { RB1 } \\
\overline{-} \\
\text { ANCR }\end{array}$ & $\begin{array}{l}\text { P } \\
\text { M } \\
\text { Isodisomy P } \\
\text { Duplication P* } \\
\text { Deletion M } \\
\text { P } \\
\text { P } \\
\text { Disomy P } \\
\text { Disomy M } \\
\text { Deletion } \mathbf{M} \\
\text { Disomy P }\end{array}$ & $\begin{array}{l}2,4 \\
10 \\
7 \mathrm{~B} 5-\mathrm{E} 3 \\
7 \mathrm{~B} 5-\mathrm{E} 3 \\
2 \mathrm{E} 4-\mathrm{F} 3 \\
9 \mathrm{~A} 4-\mathrm{B} \\
14 \mathrm{D} 2-\mathrm{E} 1 \\
12,14 \\
12,14 \\
7 \mathrm{~B} 5-\mathrm{D} 3\end{array}$ & $\begin{array}{l}\text { Yes on } 2 \text {, none on } 4 \\
\text { None } \\
\text { Yes } \\
\text { Yes } \\
\text { Yes (more distal) } \\
\text { None } \\
\text { Slight } \\
\text { Unknown on 12, slight on } 14 \\
\text { Unknown on 12, slight on } 14 \\
\text { Yes }\end{array}$ \\
\hline $15 q 11-q 13$ & Prader-Willi & PWCR & $\begin{array}{l}\text { Deletion P } \\
\text { Disomy } \mathbf{M}\end{array}$ & 7B5-D3 & Yes \\
\hline $\begin{array}{l}16 \\
17 \mathrm{q} 11.2\end{array}$ & $\begin{array}{l}\text { Intrauterine growth retardation, abortion } \\
\text { Neurofibromatosis } 1 \\
\text { (severe form) }\end{array}$ & $\overline{N F}_{1}$ & $\begin{array}{l}\text { Isodisomy } \mathbf{M}^{\dagger} \\
\mathbf{M}\end{array}$ & $\begin{array}{l}7,8,11,16,17 \\
11 \mathrm{~B} 5-\mathrm{E} 1\end{array}$ & $\begin{array}{l}\text { Yes on } 7,11,17 \\
\text { Yes (more proximal) }\end{array}$ \\
\hline $19 q 13.3$ & $\begin{array}{l}\text { Myotonic dystrophy }+ \\
\text { (severe form) }\end{array}$ & DM & $\mathbf{M}$ & 7cen-A3 & Yes \\
\hline $\begin{array}{l}20 \mathrm{q} 13.11 \\
22 \mathrm{q} 11.21- \\
\mathrm{q} 13.1\end{array}$ & $\begin{array}{l}\text { Albright's osteodystrophy } \\
\text { Neurofibromatosis } 2 \\
\text { (severe form) }\end{array}$ & $\begin{array}{l}\text { AHO } \\
\text { NF2 }\end{array}$ & $\begin{array}{l}\mathbf{M} \\
\mathbf{M}\end{array}$ & $\begin{array}{l}2 \mathrm{H} \\
10,11,15,16\end{array}$ & $\begin{array}{l}\text { Yes } \\
\text { Yes for } 11\end{array}$ \\
\hline
\end{tabular}

* Expression also with maternal inheritance; probably two genes involved.

+ Maternal disomy for chromosome 22 has also been reported but is apparently harmless, ${ }^{112113}$ as is maternal disomy for chromosome 4, paternal isodisomy for chromosome 6 , and paternal heterodisomy for the $\mathrm{X}$ and $\mathrm{Y}$ chromosomes. ${ }^{8}$

$\ddagger$ Associated with unstable DNA sequence (trinucleotide repeats). ${ }^{114}$ As with the fragile X syndrome (FRAXA) there seems to be expansion of the repeats through an ovary but not through a testis.

unique critical regions or even single genes responsible for the Angelman and PraderWilli syndromes. ${ }^{98}$

Genomic imprinting has been suspected as the mechanism behind a number of other instances of differential parental transmission of human hereditary diseases. ${ }^{8799-101}$ Those of known human location are listed in table 6, together with information on presumptive homologous regions in the mouse. Only two of the 18 entries show a clear cut discrepancy between findings in the two species. It should be remembered, however, that little is known about the actual size of imprinted regions in the mouse since those shown as such on the map $^{115}$ have been identified mainly by the aberrant behaviour of marked chromosome segments which are proximal or distal to translocation breakpoints, when heterozygotes for such translocations are intercrossed. Recent data on this point for mouse 7 concern the closely linked genes Igf 2 and $H 19$, both mapping to a distal region which is known to show imprinting effects with both maternal and paternal duplication. ${ }^{94}$ Both genes are imprinted, with only the paternal gene active in Igf $2^{116117}$ and the maternal one in H19.118 This suggests that imprinting signals are unlikely to act over large chromosomal regions. Indeed, single genes or small critical regions may be responsible for these parent of origin effects. Confirmatory evidence comes from $\operatorname{Igf} 2 r$, which codes for the Igf2 receptor gene on mouse 17. This is expressed only from the maternally inherited chromosome (that is, not from paternal disomy/maternal nullosomy) but some very closely linked genes are not subject to imprinting. ${ }^{119}$

In general, imprinting phenomena involve major effects on growth and behaviour, including overgrowth, hyperactivity, and tumours.
Mouse $I g f 2$ imprinting effects involve growth, so it is interesting to note that both this gene and $H 19$ have homologues in the short arm of human chromosome 11 , at $11 \mathrm{p} 15.5$. $^{120}$ This region seems to contain a locus for the fetal overgrowth anomaly which leads to BeckwithWiedemann syndrome (BWS) and at least two genes which predispose to Wilms's tumour, rhabdomyosarcoma, hepatoblastoma, etc. It is now clear that parent of origin effects, including paternal duplication of this region, can be found in BWS and in associated tumours as well as in Igf 2 related growth anomalies. ${ }^{121-123}$

The amount of human imprinting information derived from the detection of uniparental de novo disomies is increasing rapidly, as table 6 shows. In its nature it closely resembles that provided by heterozygotes for Robertsonian translocations in the mouse when intercrossed and is particularly useful in its scanning of a whole chromosome for effects of imprinting. Prenatal lethality because of isodisomy may be difficult to pick up in humans. Nevertheless, it may play an important role in predicting the outcome after chorionic villus sampling where mosaicism is restricted to the placenta. It has particular importance for translocation carriers. The outcome for these and the transmission of single genes which manifest imprinting will have important ramifications for genetic counselling. ${ }^{88}$ It seems clear that explanations based on genomic imprinting will play an important part in our future understanding of the origins of human hereditary disease.

\section{Discussion}

We list 214 mapped human loci with known pathological variants in which the position of the corresponding mouse locus has also been mapped. Forty two of these mouse loci $(20 \%)$ 
also have pathological variants, many of which resemble the human condition and are thus actually or potentially useful mouse models of human disease. These can throw light on the causes of the disease but can also help in developing therapies for various conditions not only at the genetic level but also in studying effects of diet changes, medication, etc. ${ }^{82}$ Gene therapy trials in humans are already being approved. ${ }^{124}$ In general, the guidelines for these suggest that animal models are developed for trials before human use. Many models are currently in use, ${ }^{125} 126$ but at present only a small proportion of human hereditary disease loci have mouse models. The situation will not improve if we wait for relevant spontaneous mutations to turn up. Among alternative strategies are the following.

(1) Mutation induction with a supermutagen, such as ethylnitrosourea (ENU). ${ }^{127}$ This has already been used successfully in mice to induce a mutant deficient in phenylalanine hydroxylase at the $\mathrm{Pah}$ locus, ${ }^{47}$ a dominant mutant at the Min (multiple intestinal neoplasia) locus which develops numerous adenomata and seems to be a homologue of the gene for familial adenomatous polyposis coli (APC), ${ }^{53}$ and a ferrochelatase deficiency at the Fech locus which leads to anaemia, photosensitivity, and liver dysfunction when homozygous. .5

(2) Targeted mutagenesis, in which a mutant cloned DNA sequence from the locus concerned is introduced into mouse pluripotent embryonal stem (ES) cells by the process of homologous recombination. The altered ES cells are then injected into mouse eight cell embryos or blastocysts, in the hope that some of these progeny will become part of the germ cell lineage and thus make the mutation heritable. ${ }^{128} 129$ As described earlier, this method has been used to generate a mutation at the $\mathrm{Hprt}$ locus in mice, while further gene targeting has led to the correction of an HPRT deficiency in an embryonic stem cell line $\mathrm{e}^{130}$ and generation of growth deficient $\operatorname{Ig} f 2$ mice. ${ }^{98}$ An extension of the targeting technique has allowed the creation of a large deletion at the $T c r b$ ( $T$ cell receptor $\beta$ subunit) locus on mouse chromosome $6 .{ }^{131}$ The successful production of mouse models of cystic fibrosis ${ }^{7172}$ and Gaucher disease $^{73}$ are other examples.

(3) Use of gene transfer techniques, with the introduction of foreign DNA, either by microinjection into the pronuclei of fertilised eggs or by retroviral infection of a specific organ. This technique has been used to remove the pathological effects of a mutant gene, for example, in shiverer (shi) mice, the locus being homologous with human MBP. The injection of normal DNA at this locus led to the production of mice with normal behaviour. ${ }^{132}$ Meisler ${ }^{133}$ has listed 13 insertional mutations at established mouse loci generated by the integration of foreign DNA within a functional gene, as well as pathological mutations at 16 previously unknown loci. Undoubtedly some of these will become mouse models of human disease. A steady flow of such models can be expected from the random insertion of micro- injected transgenes and resultant 'accidental knockouts' of genes at medically important loci.

At least 670 disease loci have now been mapped on human chromosomes, ${ }^{67}$ as compared with 214 on both human and mouse. Since many other loci have been mapped in the mouse it seems likely that a large number of human/mouse homologies for mapped loci remain to be discovered. Because so much is now known about conserved segments in the two species, the 'positional cloning' approach ${ }^{134}$ to gene identification is likely to become increasingly useful in unmasking these hidden homologies. With the development of new in situ techniques, localising the human or mouse homologue on its chromosome should become relatively simple. Once the location of the human disease gene has been mapped by pedigree analysis, then perusal of both human and mouse chromosome maps may be useful in showing 'candidate genes' if the locus lies within a conserved segment. Thus Waardenburg syndrome type I (WS1) was mapped to a region of human chromosome 2 which shares a long conserved segment with proximal mouse 1. The similar mouse gene splotch $(S p)$ was located here at the appropriate spot and was subsequently shown to be one of the paired box genes Pax-3. Affected WS1 families have been found to contain mutations in the human homologue of this gene, PAX3. These have now been found associated with Waardenburg syndrome type 3 (WS3) also. ${ }^{62}$ Similarly, human aniridia (AN2) and mouse small eye (Sey) are located in homologous regions on chromosomes 11 and 2 respectively and both are the result of mutations in Pax-6. In addition, $P a x-1$ is mutated in the chromosome 2 mouse mutant undulated (un), with vertebral and other skeletal anomalies. Thus, this set of paired box containing genes clearly comprise a vital component of the molecular mechanisms of mammalian development. ${ }^{135}$

Another recent example of a candidate gene for a human hereditary disease is PMP22 (peripheral myelin protein 22), for the Charcot-Marie-Tooth neuropathy type 1A (CMT1A). This maps to $17 \mathrm{p} 11.2$, with a mouse model trembler $(T r)$ in a conserved segment on chromosome 11. $\mathrm{Tr}$ and another allele have now been found to be mutant for Pmp22, which maps very close to this locus. ${ }^{136}$ CMT1A is associated with a DNA duplication and it has now been shown that PMP22 maps within this duplication. ${ }^{137138} \mathrm{~A}$ similar condition results from partial trisomy of human 17 including the $17 \mathrm{p}$ segment concerned.

It is not really surprising that mouse mutants at homologous loci to those responsible for human disease sometimes fail to resemble the human phenotype at all closely, since so many factors can lead to differences. Of course it is most important to be sure that the genes are truly homologous. As Darling and Abbott ${ }^{82}$ have pointed out, even if both mutate to give the same enzyme deficiency, this may affect the structural gene in one species but a regulatory gene in the other, switching off gene transcription. Introduction of a wild type structural 
gene into the latter would not correct the gene defect. Thus evidence at the DNA level is very desirable. This may well show mutations in each lineage since the common ancestral form. In view of our substantial knowledge of conserved segments, accurate location of a suspected homologue is also of great value, especially where several 'mimic genes' are rival candidates.

Even where homology is not in doubt the actual nature of the mutation may be very different in the two species, with divergent effects on development as a result. Thus in the PMP22 homology described above, the Charcot-Marie-Tooth neuropathy is the result of duplication of part of the gene while the trembler alleles in the mouse stem from base pair mutation. As mentioned earlier, even if both mutant phenotypes are deficiencies which inactivate the gene, one or both may not be entirely intragenic, so that neighbouring loci may be affected also, complicating the analysis. It should also be remembered that many mouse loci have a whole series of multiple alleles, which may have surprisingly different pleiotropic effects. Thus, at the microphthalmia $(m i)$ locus on chromosome 6 the 11 mutant alleles have a mixture of effects which involve pigmentation, size of eye, and capacity for secondary bone absorption. Pigmentation is abnormal in all, in a variety of ways, but each of the other traits is only found with some of the alleles, the most extreme of which $(m i)$ is lethal. ${ }^{9}$ The degree of dominance also varies greatly. Where homology detection is based on mutants with partial gene inactivation, therefore, comparison with a single allele may not be sufficient. Thus, one $m i$ allele $\left(m i^{v i t}\right)$ has been thought a possible homologue of human vitiligo because of its effects on pigmentation. ${ }^{139}$ However, other effects of $m i$ alleles may need consideration before the true homology can be established.

The genetic backgrounds to homologous genes cannot be the same for human and mouse chromosomes and this fact alone may lead to different phenotypic effects in the two species. It is known in the mouse that modifying genes can have a marked effect on gene expression, so placing the mouse model on a different genetic background (for example, an unrelated inbred strain) may be useful. Presumably human ethnic differences may have a similar effect. Sometimes a completely different species than the mouse may provide a more suitable model. Thus, the very slight deleterious effect of X linked muscular dystrophy in the mouse contrasts with the homologous canine condition (DMD) which is a progressive degenerative myopathy "clinically and pathologically similar to Duchenne muscular dystrophy in man". ${ }^{140}$ This seems to be a better animal model, possibly because dogs live longer than mice.

These marked interspecific differences may arise because of evolutionary changes in metabolic pathways which may, for instance, allow a toxic product to accumulate in one species but to be efficiently removed in another. Time related effects should also be considered, es- pecially when comparing species with life spans as divergent as the human $70+$ years and the mouse $2+$ years, with phenotypic classification of the latter often taking place soon after weaning age (20 to 50 weeks and 3 to 4 weeks respectively). Thus, homologues of some human hereditary diseases of late onset may not show up well in the mouse, even if they are kept until old. However, the loci concerned may still be discovered by positional cloning and other methods, as with Alzheimer disease (APP) (table 1).

Summing up, the philosophy encapsulated by Bateson's injunction: "Treasure your exceptions!" is now bearing fruit, as more and more of the mouse variants which were kept, bred, studied, and placed on the linkage and then the chromosome map are proving to be homologues of human disease loci. Thus, they can be used as models of human hereditary conditions, as appropriate subjects for gene therapy tests, and as aids to the demarcation of conserved segments and therefore to the localisation of human genes. In this respect human and mouse genetic advances can truly be called symbiotic.

We are greatly indebted to Michelle Kirby for much assistance with computer treatment of the data, to Colin Beechey for the Oxford grid (fig 2), and Theresa Kent for her patience and skill in preparing many successive drafts of this review. We are also draft.

1 Grüneberg H. Animal genetics and medicine. London: Hamish Hamilton, 1947 .

2 Nachtsheim H. Erbpathologie der Nagetiere. In: Cohrs P, Jaffé R, Meessen H, eds. Pathologie der LaboratoriumJaffe R, Meessen H, eds. Pathologie der Laboratorium
stiere. Vol 2. Berlin: Springer-Verlag, 1958:310-452.

3 O'Brien SJ, Peters J, Womack J, Marshall-Graves J, Searle AG. Report of the committee on comparative gene mapping. Chromosome coordinating meeting 1992. In: mapping. Chromosome coordinating meeting 1992. In: Cuticchia AJ, Pearson PL, Klinger HP, eds. Genom
priority reports. Vol 1. Basel: Karger, 1993:758-809.

4 priority reports. Vol 1. Basel: Karger, 1993:758-809. of man and mouse. IV. Ann Hum Genet 1989;53:89-140.

5 McAlpine PJ, Shows TB, Boucheix C, Pericak-Vance MA, Anderson WA. The 1992 catalog of mapped genes and report of the nomenclature committee. Chromosome coordinating meeting 1992. In: Cuticchia AJ, Pearson $\mathrm{PL}$, Klinger HP, eds. Genome priority reports. Vol 1. Basel: Karger, 1993:11-142.

6 McKusick VA. Mendelian inheritance in man. 10th ed. Baltimore: The Johns Hopkins University Press, 1992.

McKusick VA, Amberger JS. The morbid anatomy of the human genome: chromosomal locations of mutations causing disease. 7 Med Genet 1993;30:1-26.

8 Schinzel A, Frézal J, McKusick VA. Report of the committee on clinical disorders, chromosome aberrations and uniparental disomy. Chromosome coordinating meeting uniparental disomy. Chromosome coordinating meeting 992. In: Cuticchia AJ, Pearson PL, Klinger HP, eds. 99.

9 Green MC. Catalog of mutant genes and polymorphic loci. In: Lyon MF, Searle AG, eds. Genetic variants and In: Lyon MF, Searle AG, eds. Genetic variants and Strains of the laboratory

10 Peters J, Cocking Y. Mouse gene list. Mouse Genome 992;90:112-99.

11 Hillyard AL, Doolittle DP, Davisson MT, Roderick TH. Locus map of mouse. Mouse Genome 1993;91:15-39.

12 Lyon MF, Kirby MC. Mouse chromosome atlas. Mouse Genome 1993;91:40-80.

13 Human Gene Mapping 11. Cytogenet Cell Genet 1991;58:1-2200.

14 Domalik LJ, Chaplin DD, Kirkham MS, et al. Different isozymes of mouse 11-beta-hydroxylase produce mineralocorticoids and glucocorticoids. Mol Endocrinol $1991 ; 5: 1853-61$.

15 Ramsay M, Colman MA, Stevens G, et al. The tyrosinasepositive oculocutaneous albinism locus maps to $15 \mathrm{q} 11.2-$ q12. Am ₹ Hum Genet 1992;51:879-84.

16 Justice MJ, Gilbert DJ, Kinzler KW, et al. A molecular genetic linkage map of mouse chromosome 18 reveals extensive linkage conservation with human chromosomes 5 and 18. Genomics 1992;13:1281-8.

17 Rosen DR, Siddique T, Patterson D, Figlewicz DA, Sapp $\mathrm{P}$, Hentati $\mathrm{A}$. Mutations in $\mathrm{Cu} / \mathrm{Zn}$ superoxide dismutase gene are associated with familial amyotrophic lateral sclerosis. Nature 1993;362:59-62.

18 MacDonald G, Chu ML, Cox DR. Fine structure physical mapping of the region of mouse chromosome 10 homo- 
logous to human chromosome 21. Genomics 1991:11:31723.

19 Van Keuren M, Drabkin H, Hart I, Harker D, Patterson D, Vora S. Regional assignment of human liver-type Gphosphofructokinase to chromosome $21 \mathrm{q} 22.3$ by using somatic cell hybrids and a monoclonal anti-L antibody. Hum Genet 1986;74:34-40.

20 Nonaka M, Matsuda Y, Shiroishi T, Moriwaki K, Nonara M, Natsuume-Sakai S. Molecular cloning of mouse betatwo-glycoprotein I and mapping of the gene to chromosome 11. Genomics 1992;13:1082-7.

21 Morris DJ, Adler ID, Robinson TJ. Somatic cell hybrid mapping on mouse chromosome 11 (MMU11): assignment of markers relative to two breakpoints in band $D$. Genomics 1993;15:323-31.

22 Sato T, Saito H, Swensen J, et al. The human prohibitin gene located on chromosome $17 \mathrm{q} 21$ is mutated in sporadic breast cancer. Cancer Res 1992;52:1643-6.

23 Vance JM, Barker D, Yamnoka LH, et al. Localization of Charcot-Marie-Tooth disease type 1a (CMT1A) to chromosome 17p11.2. Genomics 1991;9:623-8.

24 Lupski JR, Montes de Oca-Luna R, Slaugenhaupt S, et al. DNA duplication associated with Charcot-Marie-Tooth disease type 1A. Cell 1991;66:219-32.

25 Miles JS, Moss JE, Taylor BA, Burchell B, Wolf CR. Mapping genes encoding drug-metabolizing enzymes in Mapping genes encoding drug-metabolizing enzymes

26 Sato H, Sakai Y, Koiwai O, Watanabe T. Mapping of the mouse bilirubin UDP-glucuronosyltransferase gene mouse bilirubin UDP-glucuronosyltransferase gene (Gnt-1) to chromosome 1 by restriction fragn

27 Marini JC, Nelson KK, Battey J, Siracusa LD. The pituitary hormones arginine vasopressin-neurophysin II and oxytocin-neurophysin I show close linkage with interleukin-1 on mouse chromosome 2 . Genomics 1993;15:200-2.

28 Vionnet N, Stoffel M, Takeda J, et al. Nonsense mutation in the glucokinase gene causes early-onset non-insulindependent diabetes mellitus. Nature 1992;356:721-2.

29 Pilz A, Moseley H, Peter J, Abbott C. Comparative mapping of mouse chromosome 2 and human chromosome 9q: the genes for gelsolin and dopamine betahydroxylase map to mouse chromosome 2. Genomics 1992;12:715-19.

30 Bahary N, Zorich G, Pachter JE, Leibel RL, Friedman JM. Molecular genetic linkage maps of mouse chromosomes 4 and 6. Genomics 1991;11:33-47.

31 Correll AT, Webb GC, Ford JH, Rogers GE, Powell BC. Localization by in situ hybridization of a type I intermediate filament gene (Kit-1.14) to band D of mouse chromosome 11. Cytogenet Cell Genet 1992;60:245-6.

32 Hovaanian A, Pollack E, Hillal L, et al. A missense mutation in the rod domain of keratin 14 associated with mutation in the rod domain of keratin 14 associated with recessive epide

33 Bonifas JM, Rothman AL, Epstein EH. Epidermolysis bullosa simplex: evidence in two families for keratin gene bullosa simplex: evidence in two families

34 Mriniuk F, Mehler M, Tzall S, Meredith G, Hirschhorn $R$. Extensive genetic heterogeneity in patients with acid alpha glucosidase deficiency as detected by abnormalities of DNA and mRNA. Am f Hum Genet 1990;47:73-8.

35 Martiniuk F, Hirschhorn R, D'Eustachio P. Linkage of acid alpha-glucosidase (Gaa) and thymidine kinase $(T k-1)$ to esterase-3 $(E s-3)$ on

36 Taym aristion in murine histidios $\mathrm{BA}$. Identification of the mutation in murine histidiaelocus (Hal) on chromosome 10. Genomics 1993;16:23140.

37 Clouston WM, Fournier REK, Richards RI. The angiotensinogen gene is located on mouse chromosome 8 . FEBS Lett 1989;255:419-22.

38 Williamson $\mathrm{P}$, Lang J, Boyd Y. The gonadotrophinreleasing hormone ( $G n r h)$ gene maps to mouse chromosome 14 and identifies a homologous region on human some 14 and identifies a homologous region on huma

2 chromosome 8. Somat Cell Mol Genet 1991;17:609-15. gamma, -delta and -epsilon genes reside within 50 kilobases on chromosome 9, whereas CD3-zeta maps to bases on chromosome 9, whereas CD3-zeta maps to
chromosome 1, band H. Immunogenetics 1989;29:265-8.

40 sligh JE, Hurwitz MY, Zhu C, Anderson DC, Beaudet AL. An initiation codon mutation in CD18 in association AL. An initiation codon mutation in CD18 in association with the moderate phenotype of leuko

41 King TR, Lee BK, Behringer RR, Eicher EM. Mapping anti-Mullerian hormone (Amh) and related sequences in anti-Mullerian hormone (Amh) and related sequences in the mouse: identification of a new region of homology 84 .

42 Steinmeyer $\mathrm{K}$, Klocke $\mathrm{R}$, Ortland $\mathrm{C}$, et al. Inactivation of muscle chloride channel by transposon insertion in myomuscle chloride channel by transposon

43 Biancalana V, Le Marec B, Odent S, van den Hurk JAMJ Hanauer A. Oto-palato-digital syndrome type I: further evidence for assignment of the locus to $\mathrm{Xq} 28$. Hum Genet 1991;88:228-30.

44 Barra J. An X-linked recessive mutation producing cleft palate, crooked tail and polydactyly in mice. $\boldsymbol{f}$ Hered 1990;81:388-92.

45 George AL, Ledbetter DH, Kallen RG, Barchi R. Assignment of a human skeletal muscle sodium channel alphasubunit gene (SCN4A) to 17q23.1-q25.3. Genomics 1991;9:555-6.
46 Ambrose C, Cheng S, Fontaine B, Nadeau JH, MacDonald M, Gusella JF. The alpha-subunit of the skeletal muscle sodium channel is encoded proximal to Tk-1 on mouse

47 McDonald JD, Bode VC, Dove WF, Shedlovsky A. $\mathrm{Pah}^{\text {hph-5: }}$ a mouse mutant deficient in phenylalanine hydroxylase. Proc Natl Acad Sci USA 1990;87:1965-7.

48 Giebel CB, Spritz RA. Mutation of the KIT (mast/stem cell growth factor receptor) protooncogene in human piebaldism. Proc Natl Acad Sci USA 1992;88:8696-9.

49 Spritz RA, Giebel LB, Holmes SA. Dominant negative and loss of function mutations of the c-kit (mast/stem cell growth factor receptor) proto-oncogene in human piebaldism. Am ₹ Hum Genet 1992;50:261-9.

50 Pohlschmidt M, Himmelbauer H, Snarey A, et al. Synteny between a region on human chromosome $16 \mathrm{p}$ containing the PKD1 gene and mouse chromosome 17. Am $\mathcal{f}$ Hum Genet 1991;49:334.

51 Himmelbauer H, Pohlschmidt $M$, Snarey A, et al. Human-mouse homologies in the region of the polycystic kidney disease gene (PKD1). Genomics 1992;13:35-8.

52 Nishisho I, Nakamura Y, Miyoshi Y, et al. Mutations of 5 q21 genes in FAP and colorectal cancer patients. Science 5q21 genes in FAP

53 Moser AR, Luongo C, Gould K, Dove WF. Multiple intestinal neoplasia (Min) in the mouse: developmental and genetical aspects. Genet Res 1992;59:235-6.

54 Bahary N, Zorich G, Plachter JE, Leibel RL, Friedman JM. Molecular genetic linkage maps of mouse chromosomes 4 and 6. Genomics 1991;11:33-47.

55 Tutois S, Montagutelli X, Vasco da Silva S, et al. Erythropoietic protoporphyria in the house mouse: a recessive poietic protoporphyria in the house mouse: a recessive inherited ferro-chelatase deficiency with anemia, photoMolecular Genetics of the Mouse, 1992.

56 Jenkins EP, Hsieh CL, Milatovich A, et al. Characterization and chromosomal mapping of a human steroid $5 \alpha-$ reductase gene and pseudogene and mapping of the mouse homologue. Genomics 1991;11:1102-12.

57 Travis GH, Christenson L, Danielson PE, et al. The human retinal degeneration slow (RDS) gene: chromosome assignment and structure of the mRNA. Genomics 1991;10:733-9.

58 Farrar GJ, Jordan SA, Kenna P, et al. Autosomal dominant retinitis pigmentosa: localization of a disease gene (RP6) to the short arm of chromosome 6. Genomics 1991;11:870-4.

59 White RA, Peters LL, Adkinson LR, Korsgren C, Cohen $\mathrm{CM}$, Lux SE. The murine pallid mutation is a platelet storage pool disease associated with the protein 4.2 (pallidin) gene. Nature Genet 1993;2:80-3.

60 Ahmad NN, Ala-Vokko L, Knowlton RG, et al. Stop codon in the procollagen II gene (COL2A1) in a family with the Stickler syndrome (arthro-ophthalmopathy). Proc Natl Acad Sci USA 1991;88:6624-7.

61 Klebig ML, Russell LB, Rinchik EM. Murine fumarylacetoacetate hydrolase (Fah) gene is disrupted by a neonatally lethal albino deletion that defines the hepatocyte-specific developmental regulation $1(h s d r-1)$ locus. cyte-specific developmental regulation 1.

62 Hoth C, Milunsky A, Lipsky N, Sheffer R, Claren SK, Baldwin CT. Mutations in the paired domain of the human PAX3 gene cause Klein-Waardenburg syndrome (WS-III) as well as Waardenburg syndrome type I (WSI). Am ₹ Hum Genet 1993;52:455-62.

63 Saunders AM, Seldin MF. The syntenic relationship of proximal mouse chromosome 7 and the myotonic dystrophy gene region on human chromosome 19q. Genomics 1990;6:324-32.

64 Lyon MF, Peters J, Glenister PH, Ball S, Wright E. The scurfy mouse mutant has previously unrecognised hematological abnormalities and resembles Wiskott-Aldrich syndrome. Proc Natl Acad Sci USA 1990;87:2433-7.

65 Davisson MT. Genetic homologies between mouse and man. Genomics 1987;1:213-27.

66 Laval SH, Boyd Y. Partial inversion of gene order within a homologous segment on the $\mathrm{X}$ chromosome. Mammal Genome 1993;4:119-23.

67 Edwards JH. The Oxford grid. Ann Hum Genet 1991;55:17-31.

68 Elliott R. DNA restriction fragment variants. Mouse Genome 1992;90:599-669.

69 Hoffman EP, Brown RH, Kunkel IM. The protein product of the Duchenne muscular dystrophy locus. Cell duct of the Duche $1987 ; 51: 919-28$.

70 Cooper BJ. Animal models of Duchenne and Becker muscular dystrophy. Br Med Bull 1989;45:703-18.

71 Snouwaert JN, Brigman KK, Latour AM, et al. An animal model for cystic fibrosis made by gene targeting. Science 1992;257:1083-8.

72 Dorin JR, Dickinson P, Alton EWFW, et al. Cystic fibrosis in the mouse by targeted insertional mutagenesis. Nature 1992:359:211-15.

73 Tybulewicz VLJ, Tremblay ML, LaMarca ME, et al. Animal model of Gaucher's disease from targeted disruption of the mouse glucocerebrosidase gene. Nature tion of the mo $357: 407-10$.

74 Jacks T, Fazeli A, Schmitt EM, Bronson RT, Goodell $M A$, Weinberg RA. Effects of an $R b$ mutation in the MA, Weinberg RA. Effects of a

75 Lee EYHP, Chang CY, Hu N, et al. Mice deficient for Rb are nonviable and show defects in neurogenesis and haematopoiesis. Nature 1992;359:288-94.

76 Kuehn MR, Bradley A, Robertson EJ, Evans MJ. A 
potential animal model for Lesch-Nyhan syndrome through introduction of HPRT mutations into mice. Nature 1987;326:295-8.

77 Hooper M, Hardy K, Handyside A, Hunter S, Monk M HPRT-deficient (Lesch-Nyhan) mouse embryos derived from germ-line colonization by cultured cells. Nature 1987;326:292-5

78 Wu CL, Melton DW. Production of a model for LeschNyhan syndrome in hypoxanthine phosphoribosyltransferase deficient mice. Nature Genet 1993;3:235-40.

79 Bulfield G, Siller WG, Wight PAL, Moore KG. X chromosome-linked muscular dystrophy $(m d x)$ in the mouse. Proc Natl Acad Sci USA 1984;81:1189-92.

80 Wiktor-Jedrzejczak WW, Bartocci A, Ferrante AW, et al. Total absence of colony-stimulating factor 1 in the macrophage deficient osteopetrotic $(o p / o p)$ mouse. Proc Nat Acad Sci USA 1990;87:4829-32.

81 Winter RM. Malformation syndromes: a review of mouse/ human homology. $\mathcal{F}$ Med Genet 1988;25:480-7.

82 Darling SM, Abbott CM. Mouse models of human single gene disorders.
$1992 ; 14: 359-66$.

83 Kozak CA. Retroviral and cancer-related genes. In: Lyon MF, Searle AG, eds. Genetic variants and strains of the laboratory mouse, 2nd ed. Oxford: Oxford University Press, 1989:404-15.

84 Roderick TH, Hillyard A, Doolittle DP, Davisson MT The use of comparative mapping to identify loci involved in human carcinogenesis. In: Detection of cancer pre1990;26(1):142-78.

85 McMahon AP. The Wnt family of developmental regulators. Trends Genet 1992;8:236-42

86 Kuo SS, Mellentin JD, Copeland NG, Gilbert DJ, Jenkins NA, Cleary ML. Structure, chromosome mapping and expression of the mouse $L y l-1$ gene. Oncogene 1991;6:961-8.

87 Hall JG. Genomic imprinting: review and relevance to human diseases. Am f Hum Genet 1990;46:857-73.

88 Hall JG. Genomic imprinting and its clinical implications. $N$ Engl $f$ Med 1992;326:827-9.

89 Cattanach BM. Chromosome imprinting and its significance for mammalian development. Genome Analysis $1991 ; 2: 41-71$

90 Knoll JHM, Nicholls RD, Magenis RE, Graham JM, Lalande M, Latt SA. Angelman and Prader-Willi syndromes share a common chromosome 15 deletion but differ in the parental origin of the deletion. Am $7 \mathrm{Med}$ Genet 1989;32:285-90.

91 Clayton Smith J, Webb T, Pembrey ME, Nichols M Malcolm S. Maternal origin of deletion 15q11-13 in 25/ 25 cases of Angelman syndrome. Hum Genet 1992;88:376-8.

92 Butler MG, Palmer GC. Parental origin of chromosome 15 deletion in Prader-Willi syndrome. Lancet 1983;1:1285-

93 Wagstaff J, Chaillet JR, Lalande M. The GABA recepto B3 subunit gene: characterization of a human $\mathrm{CDNA}$ from chromosome 15q11q13 and mapping to a region of conserved synteny on mouse chromosome 7. Genomics 1991;11:1071-8.

94 Searle AG, Beechey CV. Genome imprinting phenomen on mouse chromosome 7. Genet Res 1990;56:237-44.

95 Cattanach BM, Barr A, Evans EP, et al. A candidate mouse model for Prader-Willi syndrome which shows an absence of Snrpn expression. Nature Genet 1992;2:270-4.

96 Nicholls RD, Knoll JHM, Butler MG, Karam S, Lalande $M$. Genetic imprinting suggested by maternal heterodisomy in non deletion Prader-Willi syndrome. Nature 1989;342:281-5.

97 Malcolm S, Clayton-Smith J, Nichols M, et al. Uniparental paternal disomy in Angelman's syndrome. Lancet 1991;337:694-7.

98 Saitoh S, Kubota T, Ohta T, et al. Familial Angelman syndrome caused by imprinted submicroscopic deletio encompassing GABA-A receptor $\beta_{3}$-subunit gene. Lancet 1992;366:366-7.

99 Clarke A. Genetic imprinting in clinical genetics. In Monk M, Surani A, eds. Genomic imprinting. (Develop ment suppl.) Cambridge: Company of Biologists Ltd 1990:131-9.

100 Hall JG. How imprinting is relevant to human disease. In Monk M, Surani A, eds. Genomic imprinting. (Develop ment suppl.) Cambridge: Company of Biologists, 1990 $141-8$.

101 Solter $\mathrm{D}$. Differential imprinting and expression of maternal and paternal genomes. Annu Rev Genet 1988;22:12746.

102 Erickson RP. Chromosomal imprinting and the paren transmission: specific variation in expressivity of Huntington disease. Am $\mathcal{f}$ Hum Genet 1985;37:827

103 Heutink P, van der Mey AGL, Sandkuijl LA, et al. A gene subject to genomic imprinting and responsible for hereditary paragangliomas maps to chromosome 11q23-qter.

104 Mourou $C$, Genet $1992,1: 7-10$. Wiedemann syndrome: a demonstration of the mechanisms responsible for the excess of transmitting females. $f$

105 Scrable 1 , Cavenee W, Ghavin

Sapienza C A model for embryon Sapienza C. A model for embryonal rhabdomyosarcoma tumorigenesis that involves genome

106 Wang JC, Passage MB, Yen PH, Shapiro LJ, Mohandas TK. Uniparental heterodisomy for chromosome 14 in a phenotypically abnormal familial balanced $13 / 14$ Robertsonian translocation carrier. Am $尹$ Hum Genet 1991; 48:1069-74.

107 Temple IK, Cockwell A, Hassold T, Pettay D, Jacobs P. Ment 1991:28:511-14.

108 Kalousek DK, Langlois S, Barrett I, et al. Uniparental disomy for chromosome 16 in humans. Am $\mathcal{f}$ Hum Genet 1993;52:8-16.

109 Pentao L, Lewis RA, Ledbetter DH, Patel PI, Lupski JR. Maternal uniparental disomy of chromosome 14: association with autosomal recessive rod monochromacy. $A m \mathcal{F}$ Hum Genet 1992;50:690-9.

110 Davies SJ, Hughes HE. Imprinting in Albright's hereditary osteodystrophy. 7 Med Genet 1993;30:101-3.

111 Haas OA, Argyriou-Tirita A, Lion T. Parental origin of chromosomes involved in the translocation $t(9 ; 22)$. Nature 1992;359:414-16.

112 Kirkels VGHJ, Hustinx TWJ, Scheres JMJC. Habitual abortion and translocation $(22 \mathrm{q} ; 22 \mathrm{q})$ : unexpected transmission from a mother to her phenotypically normal daughter. Clin Genet 1980;18:456-61.

113 Palmer CG, Schwartz S, Hodes ME. Transmission of a balanced homologous $t(22 q ; 22 q)$ translocation from mother to normal daughter. Clin Genet 1980;17:418-22.

114 Harley HG, Brook JD, Rundle SA, et al. Expansion of an unstable DNA region and phenotypic variation in myotonic dystrophy. Nature 1992;355:545-6.

115 Beechey CV, Cattanach BM, Searle AG. Genetic imprinting map. Mouse Genome 1992;90:66-7.

116 DeChiara TM, Robertson EJ, Efstratiadis A. Parental imprinting of the mouse

117 Ferguson-Smith AC, Cattanach BM, Barton SC, Beechey CV, Surani MA. Embryological and molecular investigations of parental imprinting on mouse chromosome 7 . Nature 1991;351:667-70.

118 Bartolomei MS, Zemel S, Tilghman SM. Parental imprinting of the mouse H19 gene. Nature 1991;351:153-5.

119 Barlow DP, Stöger R, Herrmann BG, Saito K, Schweifer $\mathrm{N}$. The mouse insulin-like growth factor type-2 receptor
is imprinted and closely linked to the Tme locus. Nature is imprinted and

120 Glaser T, Housman D, Lewis WH, Gerhard D, Jones C. A fine-structure deletion map of human chromosome $11 \mathrm{p}$ : analysis of J1 series hybrids. Somat Cell Mol Genet 1989;15:477-501.

121 Henry I, Bonaiti-Pellié C, Chehensse V, et al. Uniparental paternal disomy in a genetic cancer-predisposing syndrome. Nature 1991;351:665-7.

122 Fidler AE, Maw MA, Eccles MR, Reeve AE. Transsensing hypothesis for origin of Beckwith-Wiedemann syndrome. Lancet 1992;339:243.

123 Norman AM, Read AP, Donnai D. Beckwith-Wiedemann syndrome. F Med Genet 1992;29:679.

124 Miller AD. Human gene therapy comes of age. Nature 1992;357:455-60.

125 Camper SA. Research applications of transgenic mice Biotechniques 1987;5:638-50.

126 Kolberg R. Animal models point the way to human clinical trials. Science 1992;256:772-3.

127 Russell WL, Kelly EM, Hunsicker PR, Bangham JW, Maddux SC, Phipps EL. Specific-locus test shows ethylnitrosourea to be the most potent mutagen in the mouse. Proc Natl Acad Sci USA 1979;76:5818-19.

128 Capecchi MR. The new mouse genetics: altering the genome by gene targetting. Trends Genet 1989;5:70-6.

129 Frohman MA, Martin GR. Cut, paste and save: new approaches to altering specific genes in mice. Cell approaches to

130 Thompson S, Clarke AR, Pow AM, Hooper ML, Melton DW. Germ line transmission and expression of a corrected HPRT gene produced by gene targeting in rected HPRT gene produced by gene

131 Mombaerts $P$, Clarke AR, Hooper ML, Tonegava S Creation of a large genomic deletion at the $T$-cell antigen
receptor $\beta$-subunit locus in mouse embryonic stem receptor $\beta$-subunit locus in mouse embryonic stem cells by gene

132 Readhead C, Popko B, Takahashi N, et al. Expression of a myelin basic protein gene in transgenic shiverer mice. Cell 1987;48:703-12.

133 Meisler MH. Insertional mutation of 'classical' and novel genes in transgenic mice. Trends Genet 1992;8:341-4.

134 Collins FS. Positional cloning: let's not call it reverse any more. Nature Genet 1992;1:3-6.

135 Gruss $\mathbb{W}, \mathbb{W}$ alther $C$. Pax in development. Cell 1992;69:719-22.

136 Suter U, Moskow JJ, Welcher AA, et al. A leucine-toproline mutation in the putative first transmembrane domain of the $22-\mathrm{kDa}$ peripheral myelin protein in the trembler-J mouse. Proc Natl Acad Sci USA 1992;89:4382-6.

137 Timmerman V, Nelis E, Van Huul W, et al. The peripheral myelin protein gene PMP-22 is contained within phe Corcotin Nature Genet 1992;1:171-5.

138 Matsunami N, Smith B, Ballard L, et al. Peripheral myelin protein-22 gene maps in the duplication in chromosome protein-22 gene maps in the duplication in chromosome Nature Genet 1992;1:176-9.

139 Tang M, Neumann PE, Kosavas B, Taylor BA, Sidman RL. Vitiligo maps to mouse chromosome 6 within or $\mathrm{RL}$. Vitiligo maps to mouse chromosome 6 within
close to the mi locus. Mouse Genome 1992;90:441-3.

140 Valentin BA, Winand NJ, Pradhan D, et al. Canine Xlinked muscular dystrophy as an animal model of Duchenne muscular dystrophy. Am $f$ Med Genet 1992;42:352-6. 